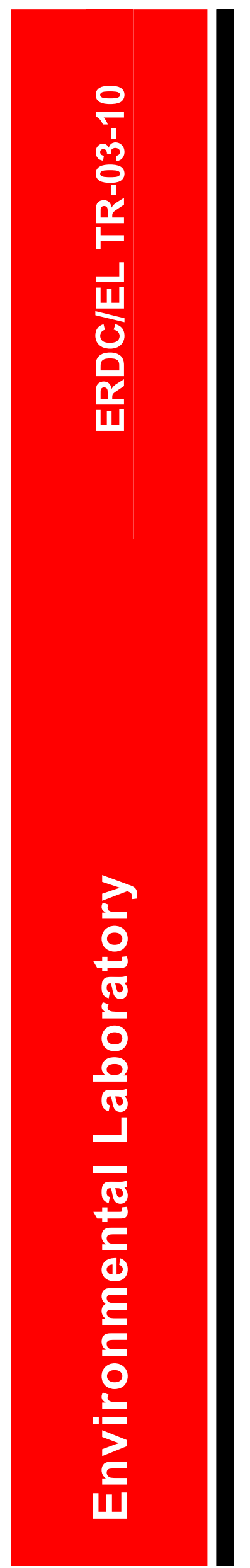

Aquatic Plant Control Research Program

\title{
Invasion of Eurasian Watermilfoil in Lakes of the Western Upper Peninsula, Michigan
}

John G. Skogerboe, Angela G. Poovey, Kurt D. Getsinger, and Greg Kudray

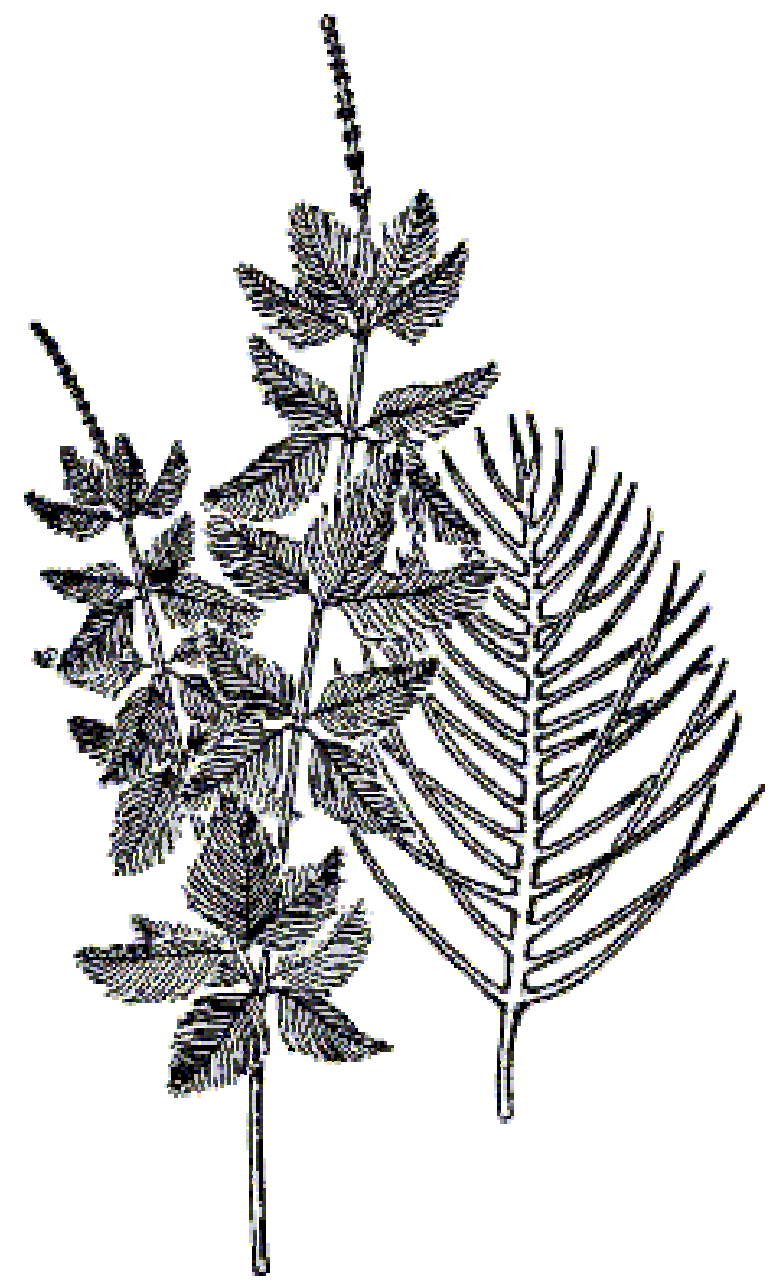




\title{
Invasion of Eurasian Watermilfoil in Lakes of the Western Upper Peninsula, Michigan
}

\author{
John G. Skogerboe \\ Lewisville Aquatic Ecosystem Research Facility \\ U.S. Army Engineer Research and Development Center \\ 1 Fish Hatchery Road \\ Lewisville, TX 75056 \\ Angela G. Poovey, Kurt D. Getsinger \\ Environmental Laboratory \\ U.S. Army Engineer Research and Development Center \\ 3909 Halls Ferry Road \\ Vicksburg, MS 39180-6199 \\ Greg Kudray \\ Ecological Inventory and Analysis \\ 38869 Klingville Road \\ Chassell, MI 49916
}

Final report

Approved for public release; distribution is unlimited

Prepared for U.S. Army Corps of Engineers

Washington, DC 20314-1000

U.S. Army Engineer District, Detroit

477 Michigan Avenue

Detroit, MI 48226 


\begin{abstract}
Eurasian watermilfoil (Myriophyllum spicatum L.) has the potential to cause major longterm adverse environmental, recreational, and aesthetic impacts to the pristine lakes in the western Upper Peninsula of Michigan. At the request of the U.S. Army Engineer District, Detroit, the U.S. Army Engineer Research and Development Center evaluated 16 lakes in Gogebic County, first to verify if Eurasian watermilfoil was present in the lakes, and then to recommend spot-treatment control options for pioneer infestation of the exotic species. Surveys were conducted using a sampling grid and global positioning system method. Of the lakes surveyed, only two contained small infestations of Eurasian watermilfoil. Occurrences of rare, threatened, or endangered aquatic plants were documented during the lake evaluations.
\end{abstract}

DISCLAIMER: The contents of this report are not to be used for advertising, publication, or promotional purposes. Citation of trade names does not constitute an official endorsement or approval of the use of such commercial products. All product names and trademarks cited are the property of their respective owners. The findings of this report are not to be construed as an official Department of the Army position unless so designated by other authorized documents. 


\section{Contents}

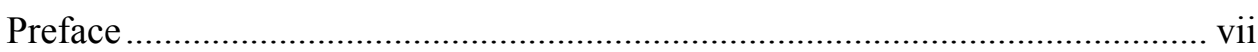

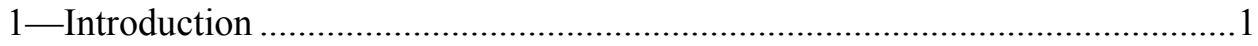

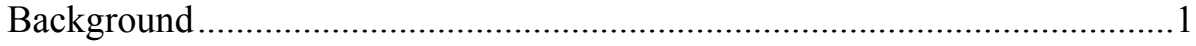

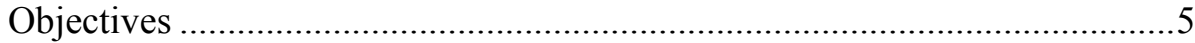

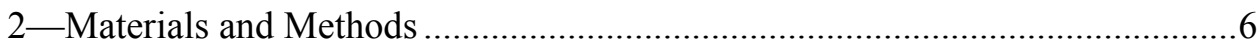

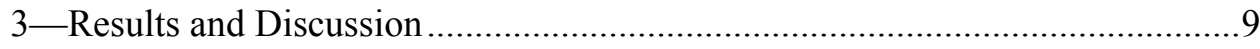

General Lake Conditions .........................................................................

Overview of Eurasian Watermilfoil Infestations and Native Plant

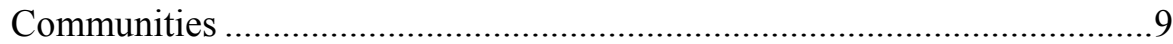

Management of Pioneer Eurasian Watermilfoil Infestations ........................14

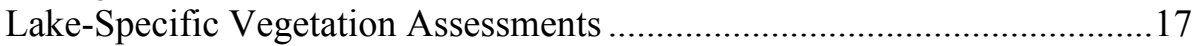

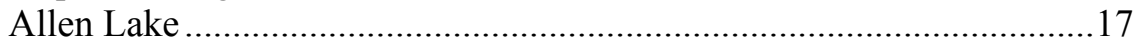

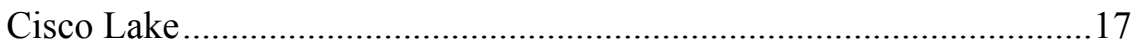

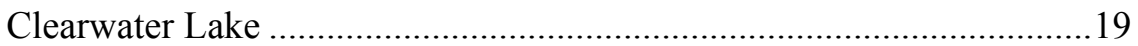

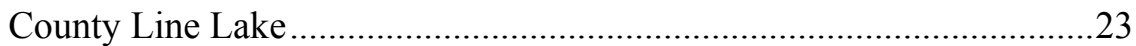

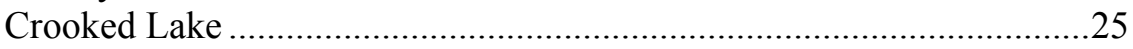

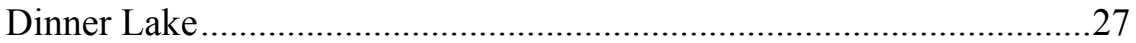

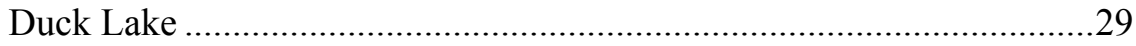

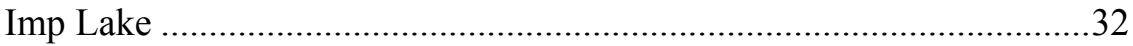

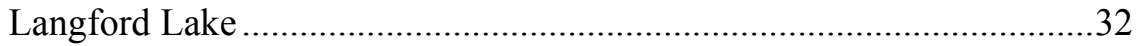

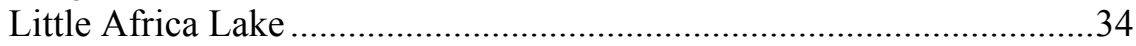

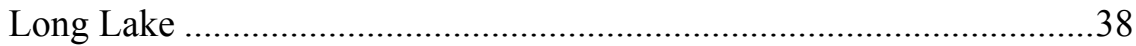

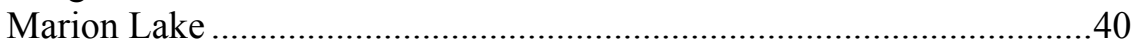

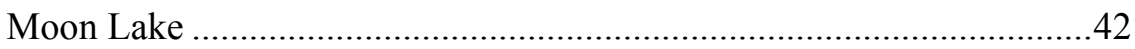

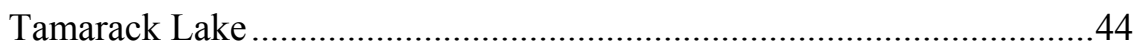

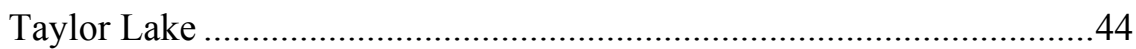

Thousand Island Lake .............................................................4

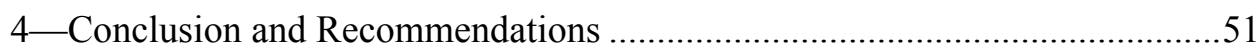

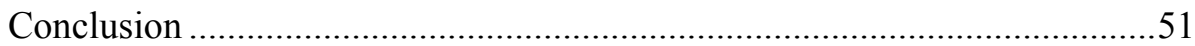

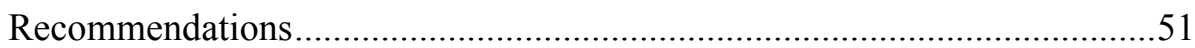

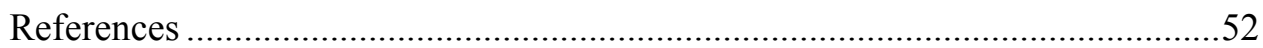

SF 298 


\section{List of Figures}

Figure 1. Gogebic County and the Watersmeet Area, MI ........................2

Figure 2. USFS Sylvania Wilderness Area, MI........................................

Figure 3. Cisco Chain of Lakes, Upper Peninsula, MI ……....................... 4

Figure 4. Location of lakes surveyed in the Michigan western Upper Peninsula, summer 2002 ............................................. 7

Figure 5. Allen Lake, Gogebic County, MI, aquatic plant survey

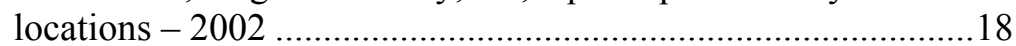

Figure 6. Cisco Lake, Gogebic County, MI, aquatic plant survey locations -2002 .20

Figure 7. Clearwater Lake, Gogebic County, MI, aquatic plant

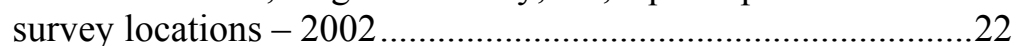

Figure 8. County Line Lake, Gogebic County, MI, aquatic plant survey locations -2002

Figure 9. Crooked Lake, Gogebic County, MI, aquatic plant

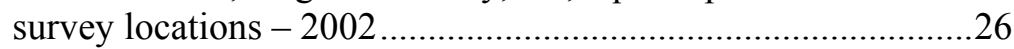

Figure 10. Dinner Lake, Gogebic County, MI, aquatic plant survey locations -2002 .28

Figure 11. Duck Lake, Gogebic County, MI, aquatic plant survey locations -2002

Figure 12. Imp Lake, Gogebic County, MI, aquatic plant survey locations -2002

Figure 13. Langford Lake, Gogebic County, MI, aquatic plant survey locations -2002 .

Figure 14. Little Africa Lake, Gogebic County, MI, aquatic plant survey locations -2002

Figure 15. Long Lake, Gogebic County, MI, aquatic plant survey locations -2002

Figure 16. Marion Lake, Gogebic County, MI, aquatic plant survey locations -2002

Figure 17. Moon Lake, Gogebic County, MI, aquatic plant survey locations -2002

Figure 18. Tamarack Lake, Gogebic County, MI, aquatic plant survey locations -2002 
Figure 19. Taylor Lake, Gogebic County, MI, aquatic plant survey locations -2002

Figure 20. Thousand Island Lake, Gogebic County, MI, aquatic plant survey locations -2002 .

\section{List of Tables}

Table 1. Michigan Lakes Surveyed in July 2002

Table 2. Summary of Vegetation Assessment for Each Lake

Surveyed in July 2002

Table 3. Aquatic Plant Species Found in Lakes of Gogebic

County, MI in July 2002

Table 4. Species Found in Lakes That Are Listed as Sensitive, Threatened, and Endangered....

Table 5. Allen Lake, Gogebic County, MI, Aquatic Plant Survey

Results - 2002

Table 6. Cisco Lake, Gogebic County, MI, Aquatic Plant Survey

Results -2002 .

Table 7. Clearwater Lake, Gogebic County, MI, Aquatic Plant

Survey Results -2002 .

Table 8. County Line Lake, Gogebic County, MI, Aquatic Plant

Survey Results - 2002 .25

Table 9. Crooked Lake, Gogebic County, MI, Aquatic Plant Survey Results -2002 .

Table 10. Dinner Lake, Gogebic County, MI, Aquatic Plant Survey

Results -2002 .

Table 11. Duck Lake, Gogebic County, MI, Aquatic Plant Survey

Results - 2002

Table 12. Imp Lake, Gogebic County, MI, Aquatic Plant Survey

Results - 2002 .34

Table 13. Langford Lake, Gogebic County, MI, Aquatic Plant

Survey Results -2002 .

Table 14. Little Africa Lake, Gogebic County, MI, Aquatic Plant

Survey Results -2002 . .38

Table 15. Long Lake, Gogebic County, MI, Aquatic Plant Survey Results -2002 . 
Table 16. Marion Lake, Gogebic County, MI, Aquatic Plant Survey Results - 2002 ..........................................................42

Table 17. Moon Lake, Gogebic County, MI, Aquatic Plant Survey

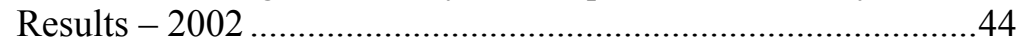

Table 18. Tamarack Lake, Gogebic County, MI, Aquatic Plant

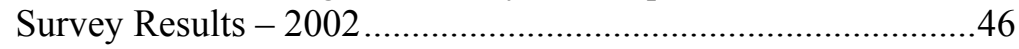

Table 19. Taylor Lake, Gogebic County, MI, Aquatic Plant Survey

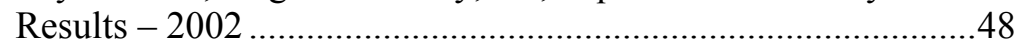

Table 20. Thousand Island Lake, Gogebic County, MI, Aquatic Plant Survey Results - 2002 ...................................................5 


\section{Preface}

The work reported here was conducted as part of the Aquatic Plant Control Research Program (APCRP). The APCRP is sponsored by Headquarters, U.S. Army Corps of Engineers (HQUSACE), and is assigned to the U.S. Army Engineer Research and Development Center (ERDC) under the purview of the Environmental Laboratory (EL), Vicksburg, MS. Funding was provided under Department of the Army Appropriation No. 96X3122, "Construction General." Support was also provided by the U.S. Army Engineer District, Detroit (LRE) coordinated through Mr. Charles Uhlarik and Mr. Joe Wanielista, LRE.

Mr. Robert C. Gunkel, Jr., was Program Manager for the APCRP. Program monitor during this study was Mr. Timothy R. Toplisek, HQUSACE.

The Principal Investigator for this research was Mr. John G. Skogerboe, Environmental Processes Branch (EPB), Environmental Processes and Engineering Division (EPED), EL, ERDC. This work was conducted and report prepared by Mr. Skogerboe, Ms. Angela G. Poovey, and Dr. Kurt Getsinger (EPB); and Dr. Greg Kudray, Ecological Inventory and Analysis, Chassell, MI.

Technical reviews were provided by Dr. Stan Nichols, Wisconsin Geological and Natural History Survey, and Ms. Susan Trull, U.S. Forest Service (USFS). Special thanks are extended to Mr. Jeff Zelinski and the Watersmeet (Michigan) Chamber of Commerce for initial development of the project and logistical support throughout the study. Ms. Trull supplied specimens of sensitive and endangered aquatic plant species from the lakes of the Ottawa National Forest. Mr. Robert Evans, Wildlife Biologist, USFS, Watersmeet Ranger District, provided maps and information on lakes in the Ottawa National Forest. We also thank Ms. Sadie Rosenthal, Ms. Margaret Kulwicki, and Ms. Samantha Stevens, University of Notre Dame Environmental Research Center, for technical assistance in sampling Clearwater and Langford Lakes.

This work was performed under the general supervision of Dr. Edwin Theriot, Director, EL; Dr. Richard E. Price, Chief, EPED; and Dr. Terrence M. Sobecki, Chief, EPB. The Commander and Executive Director of ERDC is COL James R. Rowan, EN, and the Director of ERDC is Dr. James R. Houston. 


\section{Introduction}

\section{Background}

The Gogebic County region is a rural area in the western Michigan Upper Peninsula, where the Ottawa National Forest covers 85 percent of the county (Figure 1). Included in the national forest is the Sylvania Wilderness Area (SWA; Figure 2), which is a protected area of old climax forests and numerous lakes (Peacock 1986). It is a valuable regional resource that supports a diverse vegetative community, including sensitive, threatened, and endangered (STE) species that occur both upland and along lakeshores. Because of its pristine lakes, SWA attracts many people who enjoy hiking, canoeing, and primitive camping. Hiking and portage trails that wind through forests and along lakeshores are unmarked. The U.S. Forest Service (USFS) maintains developed recreational areas north of SWA with modern campsites, picnic areas, and groomed hiking and backpacking trails.

The Cisco Chain of Lakes is a system of 15 interconnected lakes on the Michigan-Wisconsin border (Figure 3). With over 271 miles of shoreline, it is an important natural and recreational resource to the Upper Great Lakes Region. Most of these lakes lie in Gogebic County; however, some lakes extend into Wisconsin. The Michigan Department of Natural Resources (MI-DNR) maintains public access boat ramps on Thousand Island, Cisco, and Clearwater Lakes. Another public access boat ramp is maintained on Big Lake by the Wisconsin Department of Natural Resources (WI-DNR). Many of the lakes have numerous lake homes and resorts, and significant boat traffic moves throughout the system. The Cisco Chain supports an excellent fishery with walleye, musky, northern pike, bass, and panfish. Numerous other lakes are located in the Watersmeet Area, 13 of which have public access boat ramps maintained by either the USFS or the MI-DNR. The size of these lakes varies greatly, ranging from several thousand acres to less than a hundred acres. Moreover, privately owned resorts border on many area lakes.

Eurasian watermilfoil (Myriophyllum spicatum L.) has the potential to cause major long-term adverse environmental, recreational, and aesthetic impacts to the pristine lakes in the western Upper Peninsula. Therefore, it is imperative that new infestations of this invasive plant species are detected early to rapidly implement control techniques. Likewise, existing populations of Eurasian watermilfoil should be controlled to prevent regrowth and reestablishment. 


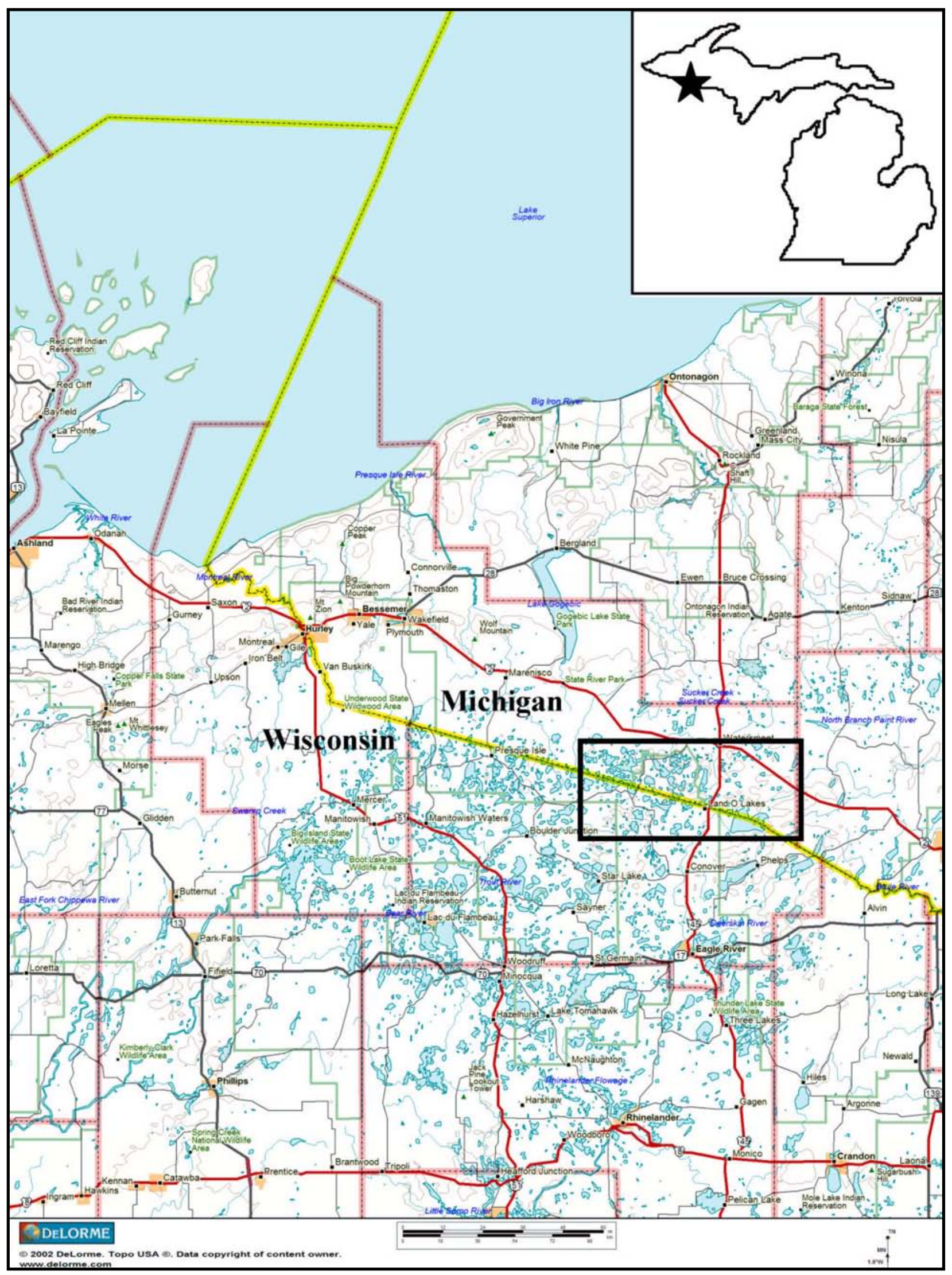

Figure 1. Gogebic County and the Watersmeet Area, MI 


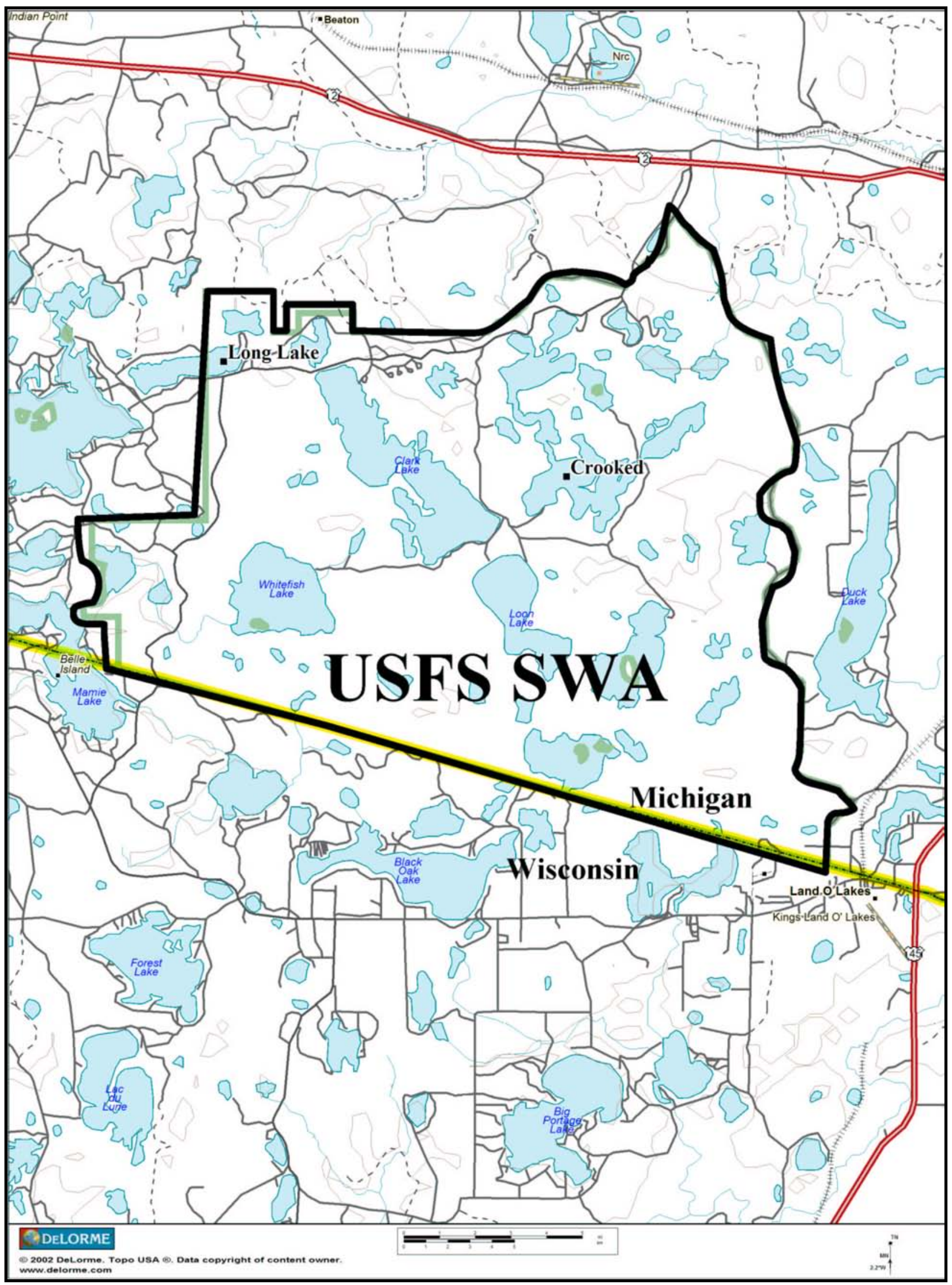

Figure 2. USFS Sylvania Wilderness Area, MI 


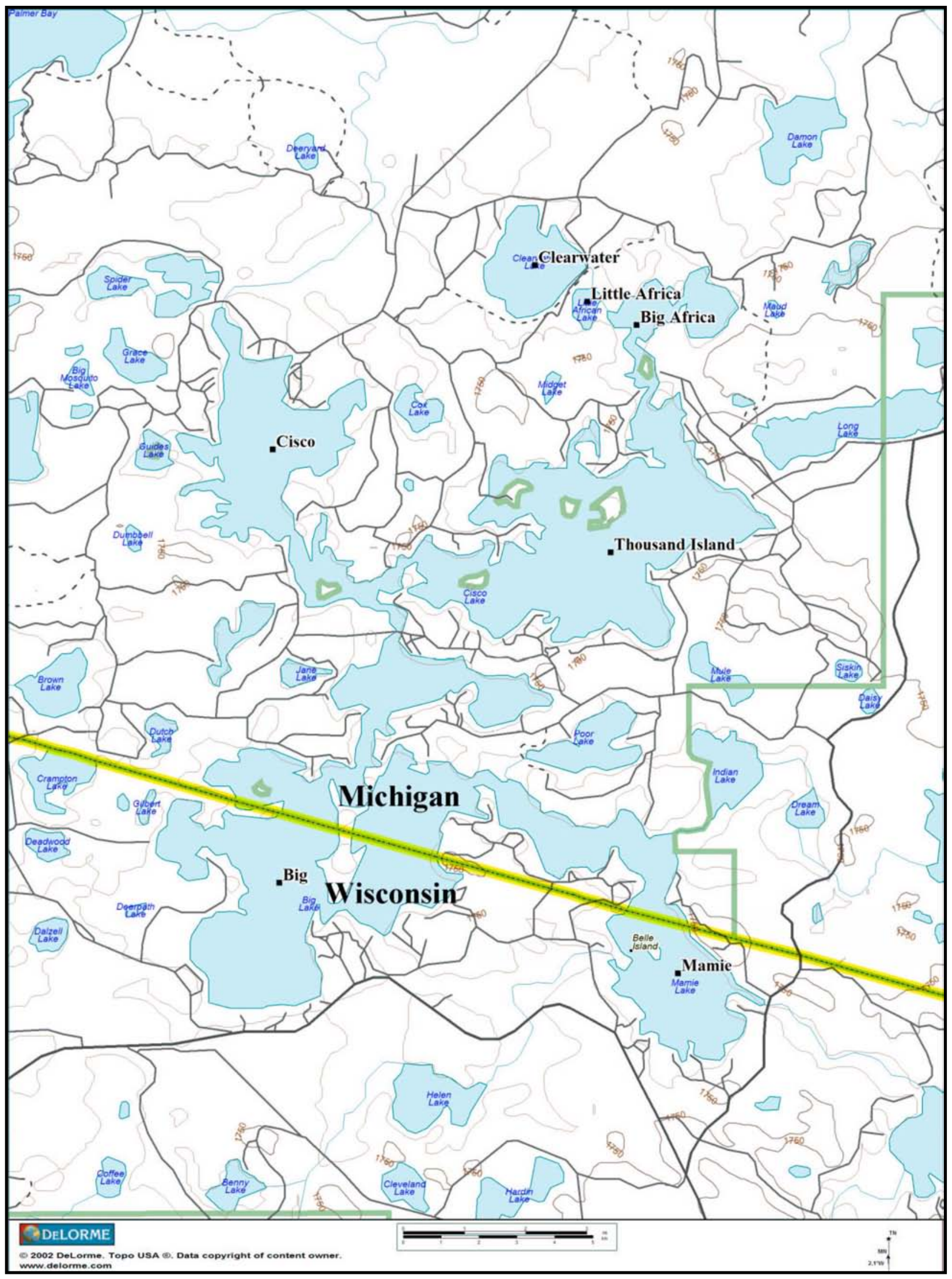

Figure 3. Cisco Chain of Lakes, Upper Peninsula, MI 
Eurasian watermilfoil was first discovered in the Cisco Chain of Lakes in 2000. It is found throughout Wisconsin, including Iron and Vilas Counties, which border Gogebic County, and throughout the Michigan Lower Peninsula. Eurasian watermilfoil ostensibly entered Clearwater Lake through a public boat access. The milfoil infestation covered 57 acres, about 34 percent of the lake surface, then most likely floated downstream to Little Africa Lake. On Little Africa Lake, the infestation was less than 1 acre. Both lakes were treated with the aquatic herbicide 2,4-D in June 2001.

In 2002 Congress tasked the U.S. Army Corps of Engineers, Detroit District to assess the aquatic plant communities of selected lakes in the western Michigan Upper Peninsula for infestations of Eurasian watermilfoil. As part of that task, the District requested the services of the U.S. Army Engineer Research and Development Center's Environmental laboratory (EL), a national research and development (R\&D) laboratory located in Vicksburg, MS. The Corps of Engineers Aquatic Plant Control Research Program (APCRP) is managed at the EL, and for more than 30 years this program has supported R\&D in the aquatic plant control arena throughout the United States. Scientists, supported by the APCRP, have extensive experience in studying the biology and management of Eurasian watermilfoil. In response to the District's request, the EL evaluated 16 lakes in Gogebic County; first, to verify if Eurasian watermilfoil was present in the lakes, many of which are hydraulically connected, and second, to recommend spot-treatment control options for pioneer infestations of this exotic species. In addition, occurrences of rare, threatened, or endangered (RTE) aquatic plants were documented during the lake evaluations. This information will be presented during an overview of key lakes in the region, and as lakespecific vegetation assessments.

\section{Objectives}

The objectives of this study were:

a. To conduct a detailed vegetation assessment on selected lakes in the western Upper Peninsula of Michigan.

$b$. Based on that assessment, determine the extent and establishment of the invasive Eurasian watermilfoil.

c. Provide recommendations for controlling/eradicating pioneer Eurasian watermilfoil infestations using environmentally compatible techniques. 


\section{Materials and Methods}

In July 2002, detailed vegetation assessments were conducted on 16 lakes in Gogebic County (Table 1). These lakes were selected based on ecological, economic, and recreational importance to the area as well as public access to the lake. Two lakes, Crooked and Long, are part of the SWA. Four lakes, Cisco, Thousand Island, Clearwater, and Little Africa, are part of the Cisco Chain of Lakes. The remaining nine lakes are scattered through the county (Figure 4).

\begin{tabular}{|c|c|c|c|c|c|}
\hline Lake & $\begin{array}{l}\text { Mean Depth } \\
\mathrm{ft}\end{array}$ & Surveyor & $\begin{array}{l}\text { Lake Area } \\
\text { acres }\end{array}$ & $\begin{array}{l}\mathrm{MSD}^{3} \\
\mathrm{ft} \\
\end{array}$ & $\begin{array}{l}\mathrm{MRD}^{4} \\
\mathrm{ft}\end{array}$ \\
\hline Allen & 14 & ERDC $^{1}$ & 79 & 10.1 & 15 \\
\hline Cisco & 11 & ERDC & 500 & 9.2 & 14 \\
\hline Clearwater & 7 & ERDC & 170 & 6.8 & 11 \\
\hline County Line & 20 & ERDC & 72 & 12.5 & 18 \\
\hline Crooked & 15 & ERDC & 566 & 19.1 & 26 \\
\hline Dinner & 11 & ERDC & 106 & 13.3 & 19 \\
\hline Duck & 7 & $\mathrm{EIA}^{2}$ & 610 & 10.1 & 15 \\
\hline Imp & 39 & ERDC & 74 & 21.5 & 29 \\
\hline Langford & 8 & ERDC & 476 & 6.8 & 11 \\
\hline Little Africa & 7 & ERDC & 18 & 5.1 & 9 \\
\hline Long & 15 & EIA & 168 & 12.5 & 18 \\
\hline Marion & 17 & ERDC & 252 & 11.7 & 17 \\
\hline Moon & 20 & ERDC & 93 & 29.7 & 39 \\
\hline Tamarack & 11 & ERDC & 283 & 5.1 & 9 \\
\hline Taylor & 20 & EIA & 162 & 6.0 & 10 \\
\hline Thousand Island & 27 & ERDC & 1,000 & 12.5 & 18 \\
\hline \multicolumn{6}{|c|}{$\begin{array}{ll}1 & \text { U.S. Army Engineer Research and Development Center. } \\
2 & \text { Ecological Inventory and Analysis. } \\
3 & \text { Mean secchi depth. } \\
{ }^{4} & \text { Maximum rooting depth. } \\
\end{array}$} \\
\hline
\end{tabular}

A 328 - $\mathrm{ft}$ by 328 -ft sampling grid was developed for each lake to be surveyed using Garmin MapSource topographic software (Olathe, KS). The sampling grid was downloaded to a Garmin ${ }^{\mathrm{TM}}$ 76C Global Positioning System (GPS) and each sample point was located and recorded as a permanent site using the GPS. Water depth at each sample point was recorded. If depth was less than or equal to the maximum rooting depth (MRD) of submersed plants, then the point was sampled to determine the presence or absence of aquatic plant species. Maximum rooting was determined from the mean secchi depth (MSD) of each lake using the equation $\mathrm{MRD}=2.73+1.22 \times \mathrm{MSD} \mathrm{ft}($ Nichols 1999). A device constructed 


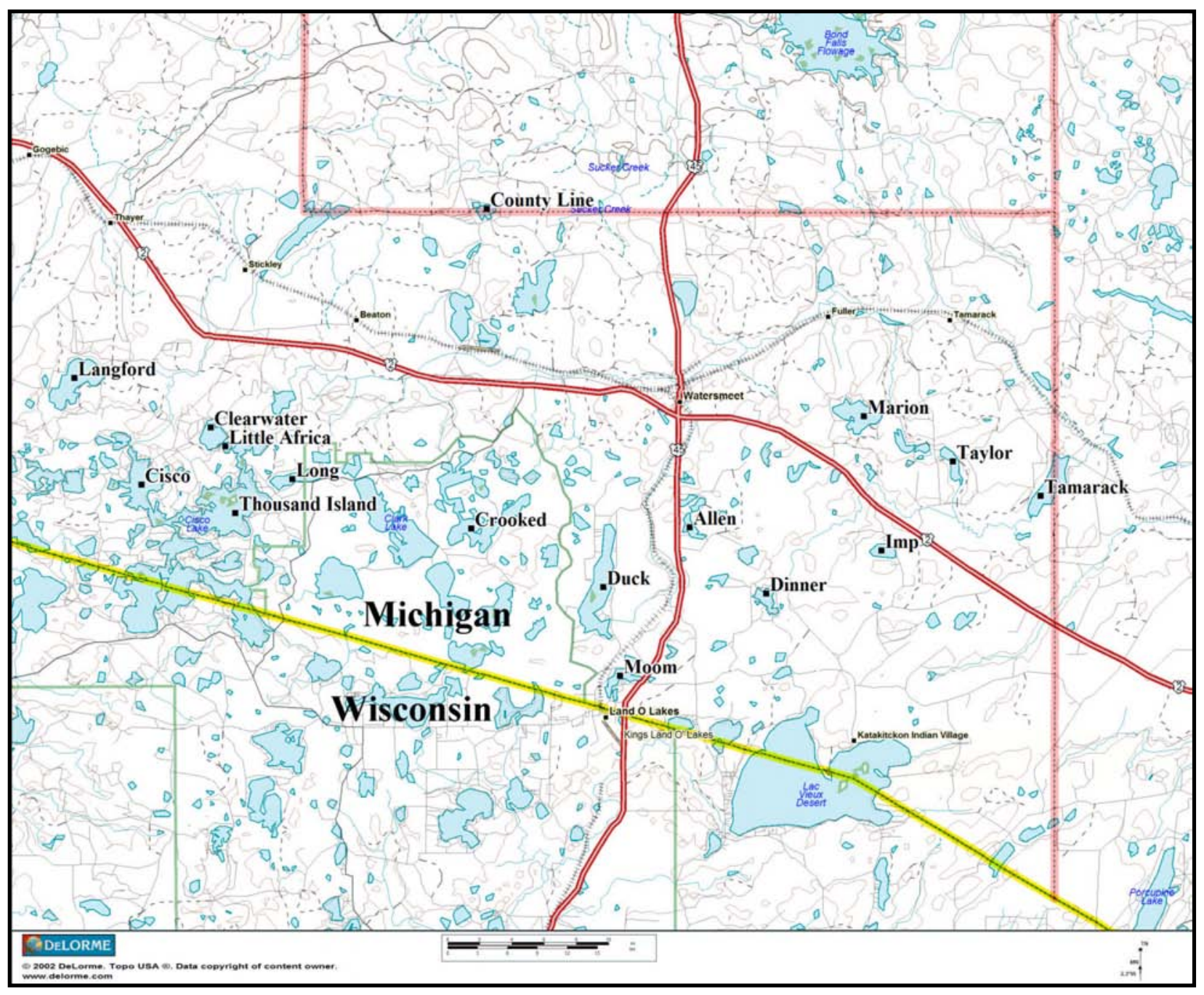

Figure 4. Location of lakes surveyed in the Michigan western Upper Peninsula, summer 2002

from two garden rake heads tied or welded together and attached to a rope was used for plant sampling. The device was thrown twice 10 to $20 \mathrm{ft}$ from the boat and dragged back to the boat along the lake bottom. All plant species attached to the device were identified (Borman et al. 1997; Crow and Hellquist 2000a; Crow and Hellquist 2000b) and recorded. Eurasian watermilfoil and curlyleaf pondweed (Potamogeton crispus L.), another invasive exotic species, were also observed visually from the surface while traversing from one sample point to another. These locations were recorded and boundaries of these plant colonies were mapped using a GPS. Voucher samples to document plant identification were collected and sent to the University of Michigan Herbarium (Ann Arbor, MI) for verification and archiving. Species listed as USFS, Regional Forester's Sensitive Plants (RFSS) or listed as STE plant species for Michigan, Wisconsin, or Minnesota were also identified. 
Since light may determine plant species distribution in a lake (Barko et al. 1986), secchi depth as light transparency measurements may indicate where Eurasian watermilfoil might invade a lake. For each lake, the potential area that could be infested by watermilfoil was calculated by determining the percentage of sample points that were less than or equal to the MRD and by determining the percentage of points that currently supported aquatic plants. The percent occurrence of a plant species was determined by the number of points a species occurred divided by the total number of sampling points in each lake (Madsen 1999).

Plant communities were qualitatively evaluated using the Wisconsin Floristic Quality Assessment (WFQA) system (Griffin and Bernthal 2003). The WFQA system uses a coefficient of conservatism $(\mathrm{CoC})$ to rank each plant species on a scale of 0 to 10 . A plant with a CoC of 10 would most likely be found only in a pristine natural community or pre-settlement condition; conversely, a plant with a $\mathrm{CoC}$ of 0 could be found anywhere, but would most likely be found in highly disturbed or degraded areas. The floristic quality index $(I)$ of each lake was determined by multiplying the square root of the number of species $(\sqrt{ } N)$ by the average $\mathrm{CoC}\left(\mathrm{CoC}_{\mathrm{avg}}\right)$ for all species found in that lake: $I=\mathrm{CoC}_{\mathrm{avg}} * \sqrt{N}$ (Nichols 1999). 


\section{Results and Discussion}

\section{General Lake Conditions}

All lakes in the Cisco Chain, except Little Africa, were well developed with shoreline residences, as were most of the other surveyed lakes. Because it was part of the SWA, Long Lake was undeveloped. Crooked Lake, although part of the SWA, was developed on the north end; consequently, residents and guests of these houses and resorts were allowed to use motorized boats. Lake surface area ranged from 18 acres on Little Africa Lake to 1,000 acres on Thousand Island Lake (Table 1). Mean depths ranged from $7 \mathrm{ft}$ in Clearwater and Little Africa Lakes to $39 \mathrm{ft}$ in Imp Lake (Table 1). Most lakes assessed had mean depths of between 10 and $20 \mathrm{ft}$. Secchi depth readings ranged from $5.1 \mathrm{ft}$ at Little Africa and Tamarack Lakes to $29.7 \mathrm{ft}$ at Moon Lake, and the resulting MRD ranged from 9 to $38 \mathrm{ft}$ (Table 1). Three lakes had MRD greater than $20 \mathrm{ft}$ and two had an MRD of less than $10 \mathrm{ft}$. The percentage of sample points with water depths $<$ MRD ranged from 33 percent on Allen Lake to 100 percent on Moon Lake (Table 2).

\section{Overview of Eurasian Watermilfoil Infestations and Native Plant Communities}

No Eurasian watermilfoil was found in the plant surveys conducted on Clearwater and Little Africa Lakes, which were the sites of infestations in 2000. Because of the selective use of 2,4-D in 2001, these lakes continued to support large stands of native vegetation. Based on the 2002 aquatic plant survey, Clearwater Lake had the highest percentage of sample points with aquatic plants of any of the lakes surveyed (70 percent), most numerous species (22), and the highest $\mathrm{CoC}_{\text {avg }}$ rating (6.7) of any lake in the Cisco Chain of Lakes (Table 2). The $I$ was relatively high (31.4).

Eurasian watermilfoil was found in Crooked and Langford Lakes. Both infestations were small and in the immediate vicinity of the USFS public access boat ramps. Five individual plants were found at Crooked Lake within $100 \mathrm{ft}$ of the boat ramp; these plants were pulled and removed by hand. The infestation at Langford Lake consisted of scattered plants along a 100-yd band on either side of the boat ramp. The infestation extended about $50 \mathrm{ft}$ out from the ramp. 


\begin{tabular}{|c|c|c|c|c|c|c|c|c|}
\hline \multicolumn{9}{|c|}{$\begin{array}{l}\text { Table } 2 \\
\text { Summary of Vegetation Assessment for Each Lake Surveyed in July } \\
2002\end{array}$} \\
\hline Lake & $\begin{array}{l}\text { Total } \\
\text { Sample } \\
\text { Pts }\end{array}$ & $\begin{array}{l}\text { Total No. } \\
\text { Pts } \\
<\text { MRD }^{1}\end{array}$ & $\begin{array}{l}\% \text { of Pts } \\
<\text { MRD }\end{array}$ & $\begin{array}{l}\text { No. of } \\
\text { Pts with } \\
\text { Plants }\end{array}$ & $\begin{array}{l}\% \text { of Pts } \\
\text { with } \\
\text { Plants }\end{array}$ & $\begin{array}{l}\text { Total No. } \\
\text { Plant } \\
\text { Species }\end{array}$ & $\mathrm{CoC}_{\mathrm{avg}}{ }^{2}$ & $I^{3}$ \\
\hline Allen & 40 & 13 & 33 & 12 & 30 & 15 & 6.9 & 26.7 \\
\hline Cisco & 223 & 153 & 69 & 134 & 60 & 23 & 6.6 & 32.1 \\
\hline Clearwater & 80 & 66 & 83 & 56 & 70 & 22 & 6.7 & 31.4 \\
\hline County Line & 37 & 20 & 54 & 11 & 30 & 7 & 7.4 & 19.6 \\
\hline Crooked & 281 & 245 & 87 & 156 & 56 & 28 & 6.5 & 33.8 \\
\hline Dinner & 50 & 45 & 90 & 17 & 34 & 15 & 6.5 & 25.9 \\
\hline Duck & 247 & 116 & 47 & 109 & 44 & 31 & 7.1 & 39.5 \\
\hline $\operatorname{Imp}$ & 37 & 11 & 30 & 9 & 22 & 12 & 7.9 & 27.4 \\
\hline Langford & 207 & 135 & 65 & 95 & 46 & 31 & 6.8 & 37.1 \\
\hline Little Africa & 12 & 7 & 58 & 7 & 58 & 13 & 6.6 & 23.9 \\
\hline Long & 68 & 44 & 65 & 34 & 50 & 19 & 7.8 & 34.0 \\
\hline Marion & 109 & 62 & 57 & 27 & 25 & 19 & 7.3 & 31.8 \\
\hline Moon & 29 & 29 & 100 & 10 & 34 & 12 & 7.5 & 26.0 \\
\hline Tamarack & 146 & 48 & 33 & 27 & 18 & 14 & 6.0 & 22.4 \\
\hline Taylor & 52 & 16 & 31 & 12 & 23 & 22 & 6.4 & 30.0 \\
\hline Thousand Island & 429 & 181 & 42 & 146 & 34 & 31 & 6.5 & 36.0 \\
\hline
\end{tabular}

In addition, one Eurasian watermilfoil specimen was collected from Big Africa Lake, which is in the Cisco Chain of Lakes downstream from Little Africa Lake and upstream from Thousand Island Lake; however, no additional Eurasian watermilfoil was found. No Eurasian watermilfoil was found in any of the other lakes surveyed.

The percentage of sample points that supported aquatic vegetation ranged from 14 percent on Imp Lake to 70 percent on Clearwater Lake (Table 2). All plants occurred at sample points $\leq$ the MRD in all of the lakes surveyed. A total of 69 different submersed and emergent aquatic plant species were found in the 16 lakes surveyed (Table 3). Five species found in the plant survey have an official designation of RFSS, either in the Ottawa National Forest or other regional national forests, or designation as STE in Michigan, or the nearby states of Wisconsin and Minnesota (Table 4). Of the five STE species recorded, Myriophyllum farwellii was found in the greatest number of the lakes. Any Eurasian watermilfoil management strategies would have to consider impacts on STE plant species. The median $\mathrm{CoC}_{\mathrm{avg}}$ rating calculated from all the species found in the vegetation assessment was 6.7 (Table 2), which indicated the lakes supported vegetation that grew in mostly undisturbed or pristine areas. The median $I$ was 30.7 (Table 2), which corresponds to high floristic quality. 


\begin{tabular}{|c|c|c|}
\hline \multicolumn{3}{|c|}{$\begin{array}{l}\text { Table } 3 \\
\text { Aquatic Plant Species Found in Lakes of Gogebic County, MI in } \\
\text { July } 2002\end{array}$} \\
\hline Scientific Name & Common Name $^{1}$ & CoC Rating $^{2}$ \\
\hline Brasenia schreberi & Water-shield & 6 \\
\hline Carex lasiocarpa & Sedge & 9 \\
\hline Ceratophyllum demersum & Coontail & 3 \\
\hline Chara spp & Muskgrass & \\
\hline Dulichium arundinaceum & Three-way Sedge & 9 \\
\hline Elatine minima & Waterwort & 9 \\
\hline Eleocharis acicularis & Needle spikerush & 5 \\
\hline Eleocharis palustris & Creeping spikerush & 6 \\
\hline Eleocharis smallii & Spikerush & 6 \\
\hline Elodea canadensis & Common waterweed & 6 \\
\hline Equisetum fluviatile & Water horsetail & 7 \\
\hline Eriocaulon aquaticum & Pipewort & 9 \\
\hline Glyceria borealis & Northern manna grass & 8 \\
\hline Gratiola aurea & Golden pert & 10 \\
\hline Iris versicolor & Northern blue flag & 5 \\
\hline Isoetes lacutris & Lake quillwort & 8 \\
\hline Isoetes echinospora & Spiny-spored quillwort & 8 \\
\hline Isoetes spp & Quillwort & 8 \\
\hline Juncus brevicaudatus & Rush & 6 \\
\hline Juncus effusus & Soft rush & 4 \\
\hline Juncus pelocarpus & Brown-fruited rush & 8 \\
\hline Lemna triscula & Forked duckweed & 6 \\
\hline Lobelia dortmanna & Water lobelia & 10 \\
\hline Lysimachia terrestris & Bulbil loosestrife & 7 \\
\hline Megalodonta beckii & Water marigold & 8 \\
\hline Myriophyllum farwellii & Farwell's watermilfoil & 8 \\
\hline Myriophyllum sibiricum & Northern watermilfoil & 6 \\
\hline Myriophyllum spicatum & Eurasian watermilfoil & \\
\hline Myriophyllum tenellum & Dwarf watermilfoil & 10 \\
\hline Najas flexilis & Slender naiad & 6 \\
\hline Nuphar advena & Yellow pond lily & 8 \\
\hline Nuphar lutea ssp variegata & Spatterdock & 6 \\
\hline Nymphaea odorata & White water lily & 6 \\
\hline Phragmites australis & Giant reed & 1 \\
\hline Pontedaria cordata & Pickerelweed & 8 \\
\hline Polygonum amphibium & Water smartweed & 5 \\
\hline Potamogeton alpinus & Alpine pondweed & 9 \\
\hline Potamogeton amplifolius & Large-leaf pondweed & 7 \\
\hline Potamogeton epihydrus & Ribbon-leaf pondweed & 8 \\
\hline Potamogeton friesii & Frie's pondweed & 8 \\
\hline & & (Continued \\
\hline
\end{tabular}




\begin{tabular}{|c|c|c|}
\hline Scientific Name & Common Name ${ }^{1}$ & CoC Rating ${ }^{2}$ \\
\hline Potamogeton gramineus & Variable pondweed & 7 \\
\hline Potamogeton natans & Floating-leaf pondweed & 5 \\
\hline Potamogeton pusillus & Small pondweed & 7 \\
\hline Potamogeton pusillus ssp tenuissimus & Small pondweed & 7 \\
\hline Potamogeton richardsonii & Clasping-leaf pondweed & 5 \\
\hline Potamogeton robbinsii & Robbins pondweed & 8 \\
\hline Potamogeton spirillus & Spiral-fruited pondweed & 8 \\
\hline Potamogeton zosteriformis & Flat-stem pondweed & 6 \\
\hline Ranunculus flammula & Creeping spearwort & 9 \\
\hline Rannuculus flammula var. filiformis & Creeping spearwort & 9 \\
\hline Ranunculus longirostris & Stiff water crowfoot & 8 \\
\hline Riccia fluitans & Slender riccia & 7 \\
\hline Sagittaria graminea var. cristata & Grass-leaved arrowhead & 9 \\
\hline Sagittaria latifolia & Common arrowhead & 3 \\
\hline Scirpus tabernaemontani & Soft-stemmed bulrush & 4 \\
\hline Scirpus acutus & Hardstem bulrush & 6 \\
\hline Scirpus subterminalis & Water bulrush & 9 \\
\hline Sparganium augustifolium & Narrow-leaf bur-reed & 9 \\
\hline Sparganium chlorocarpum & Short-stemmed bur-reed & 8 \\
\hline Sparganium eurycarpum & Common bur-reed & 5 \\
\hline Sparganium fluctuans & Floating-leaf bur-reed & 10 \\
\hline Stuckenia pectinata & Sago pondweed & 3 \\
\hline Typha latifolia & Broad-leaved cattail & 1 \\
\hline Utricularia intermedia & Flat-leaf bladderwort & 9 \\
\hline Utricularia vulgaris & Bladderwort & 7 \\
\hline Utricularia resupinata & Small purple bladderwort & 9 \\
\hline Vallisneria americana & Wild celery & 6 \\
\hline Zizania aquatica & Wild rice & 8 \\
\hline Zosterella dubia & Water stargrass & 6 \\
\hline
\end{tabular}

Tamarack Lake was unique because the water was stained with tannins and humic acids that caused low visibility. The percentage of sample points supporting vegetation in Tamarack was relatively low (18 percent) as was the number of species found (12). Consequently, the $\mathrm{CoC}_{\mathrm{avg}}$ rating was the lowest of the lakes surveyed (6.0) and the $I$ was 22.4 (Table 2).

On lakes such as County Line, Dinner, Long, Marion, and Moon, there were high percentages ( $>50$ percent) of sample points less than the MRD; however, the percentage of sample points that actually supported vegetation was much lower ( $<35$ percent). These lakes were very clear, with sand, gravel, and rocky substrates and would be classified as oligotrophic. While the MRD indicated that plants could grow in deeper water, substrates may have inhibited plant 


\begin{tabular}{|c|c|c|c|c|c|c|}
\hline Species & $\begin{array}{l}\text { USDA ID } \\
\text { Code }^{1}\end{array}$ & $\begin{array}{l}\text { No. of } \\
\text { Lakes }\end{array}$ & RFSS & MI & WI & MN \\
\hline Gratiola aurea & GRAU & 1 & & $T^{4}$ & $\mathrm{Sc}^{5}$ & \\
\hline Myriophyllum farwellii & MYFA2 & 4 & $\mathrm{ONF}^{2}$ & $\mathrm{~T}$ & sc & \\
\hline Scirpus subterminalis & SCSU10 & 3 & ONF & & & \\
\hline Utricularia resupinata & UTRE & 3 & Other ${ }^{3}$ & & $\mathrm{SC}$ & SC \\
\hline Zizania aquatica & ZIPA3 & 1 & & & & \\
\hline \multicolumn{7}{|c|}{ 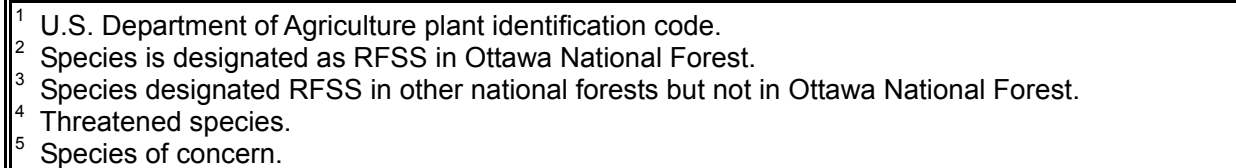 } \\
\hline
\end{tabular}

colonization. Common submersed plant species in these lakes included Lobelia dortmanna, Myriophyllum tenellum, Eleocharus sp, Brasenia schreberi, and Ranunculus flammula. Although $\mathrm{CoC}_{\mathrm{avg}}$ ratings for these lakes ranged from 7.1 to 7.8 (Table 2), I values ranged from 19.6 to 34.0 (Table 2).

Other lakes, particularly those in the Cisco Chain of Lakes, and Duck, Crooked, Langford, and Taylor Lakes, had softer silt sediments that were more amenable to aquatic vegetation colonization. Common submersed plant species included large stands of mixed Potamogeton spp., Myriophyllum sibiricum, Elodea canadensis, and Vallisneria americana. The percentage of points supporting vegetation was similar to the percentage of points with water depths less than the MRD (Table 2). These lakes also supported more species diversity ( $>20$ species), but received lower $\mathrm{CoC}_{\text {avg }}$ ratings (6.4 to 6.7; Table 2); however, $I$ values for these lakes were higher (30 to 39.5; Table 2) than the oligotrophic lakes.

Differences between western Upper Peninsula oligotrophic lakes and lakes of the Cisco Chain are similar to those reported for the lakes of Northern Forests and Lakes (NFLL) and the flowages of Northern Forests and Lakes (NFLF) of Wisconsin (Nichols 1999). Number of species reported for the NFLL ranged from 10.8 to 31.3 , the median $\mathrm{CoC}_{\text {avg }}$ rating was 6.2 , and the median $I$ value was 28.3; these values correspond to lakes found in the Cisco Chain. Number of species reported for the NFLF ranged from 7 to 20, the median $\mathrm{CoC}_{\text {avg }}$ rating was 6.7 , and the median $I$ value was 24.3 ; these values correspond to oligotrophic lakes.

Native aquatic plant communities of Gogebic County lakes were diverse and abundant. Based on the WFQA system, native plant communities were characterized as mostly pristine, typically found in isolated or well-protected areas. The SWA is a protected wilderness area, yet Crooked Lake had a small infestation of Eurasian watermilfoil, which was also found in Langford Lake. Both infestations were found near the public access boat ramps. 
Clearly, Eurasian watermilfoil is threatening to become established in Gogebic County. Based on the currently published literature (Smith and Barko 1990), exact predictions cannot be made on the magnitude of the effect Eurasian watermilfoil will have if it becomes permanently established. From vegetation assessments, the Cisco Chain of Lakes, lakes in the SWA, Duck Lake, and Langford Lake probably have the highest risk of developing nuisance-level infestations. Plants found in these lakes indicated conditions were more conducive to rapid expansion of new infestations (Nichols and Buchan 1997). Moreover, the MRD data also indicated that many of these lakes could potentially support 50 to 70 percent coverage of the surface, which would be detrimental to native plant and animal communities as well as recreation and aesthetics. The small oligotrophic lakes found scattered throughout Gogebic County were less likely to support large, dense stands of Eurasian watermilfoil even though the secchi depth and MRD data indicated that plants could cover much of the lake surface area. Types of plants found in these lakes suggested that substrate and available nutrients may not be adequate to support rapid expansion of Eurasian watermilfoil, if it were introduced. Small, submersed colonies of Eurasian watermilfoil may not pose a threat to recreation and aesthetic appeal, but could be a threat to these fragile shoreline native plant communities. Moreover, small Eurasian watermilfoil populations would be a source for other infestations.

Past experience at Clearwater Lake has shown that, once Eurasian watermilfoil is introduced, it rapidly expands and moves into nearby interconnected lakes such as Little Africa and Big Africa. However, if managed early with appropriate control techniques, Eurasian watermilfoil may be stopped and possibly eradicated. Results of the 2002 aquatic plant survey on Clearwater and Little Africa Lakes demonstrated that applying aquatic herbicides selectively controls not only the invading exotic plants, but protects valuable native plant communities, including STE species. Early detection of exotic plant invasions is vital to stopping new infestations from becoming established, maximizing protection of native plant communities, and minimizing the cost of control.

\section{Management of Pioneer Eurasian Watermilfoil Infestations}

Eurasian watermilfoil is an exotic aquatic plant that has been in Wisconsin and Michigan since the early 1970s (Nichols 1994), and negatively impacts biotic and abiotic lake interactions (Nichols and Shaw 1986; Smith and Barko 1990). Formation of dense surface canopies by species such as Eurasian watermilfoil reduce native plant diversity and abundance (Madsen et al. 1991; Boylen et al. 1999), resulting in a decrease in aquatic macroinvertebrate diversity (Keast 1984). Moreover, when plant coverage exceeds 30 percent of a lake littoral zone, predatory fish such as bass remain small, causing overall fish production to decline (Colle and Shireman 1980; Wiley et al. 1984; Engel 1995; Valley and Bremigan 2002). Abiotic components adversely affected by Eurasian watermilfoil's dense surface canopies are reviewed in Getsinger et al. (2002) and include anoxia below the canopy, enhanced nutrient cycling, and strong vertical gradients in $\mathrm{pH}$ and temperature. Pullman (1992) outlines characteristics of Eurasian 
watermilfoil that have contributed to its establishment as a major nuisance in Michigan's water resources.

Management techniques for controlling Eurasian watermilfoil in an environmentally sound manner include the use of an indigenous weevil (Euhrychiopsis lecontei (Dietz)) as a biocontrol agent. Predictable long-term control using the weevil as an operational tool has been inconsistent (Getsinger et al. 2002). In addition, refinement of stocking rates and a better understanding of life-cycle/ population dynamics is needed. An excellent review of these techniques for control of Eurasian watermilfoil in a large Michigan inland lake is provided by Getsinger et al. (2002). Other techniques are more suitable for controlling pioneer infestations of Eurasian watermilfoil, including benthic barriers, hand pulling, diver-operated suction dredging, and use of aquatic herbicides (Madsen 2000).

Benthic barriers serve as blankets blocking light for plant growth or screens physically preventing plant growth. They are usually installed early in the spring right after ice out (Perkins et al. 1980) for one to several months. Synthetic sheeting that blankets the sediment surface may lift away from the lake bottom due to the evolution of gases from plant decomposition (Gunnison and Barko 1992). Screen barriers need to be maintained and cleaned regularly to provide multiple years of control (Engel 1984; Eichler et al. 1995). Because benthic barriers are not species selective, it is considered only when small patches of Eurasian watermilfoil are present or in areas that are ecologically sensitive.

Hand pulling is the most common form of aquatic plant control by lakeshore owners throughout the United States (Madsen 2002). Hand cutters, rakes, or bare hands remove vegetation along shorelines and around boat docks. SCUBA divers can also hand-pull vegetation near the sediment surface to remove the roots and rhizome systems. This method is labor intensive, but hand pulling is selective and can be effective in very localized areas ( $<1$ acre). Plant beds that are too large to hand pull may be removed by a diver-operated suction dredge. A suction dredge is a hydraulic vacuum system created by a fuel-generated pump borrowed from the gold-mining industry. Divers use this method to selectively harvest vegetative stems and roots without removing the sediments. Although this method is labor intensive, it significantly reduces biomass and limits regrowth of the target plant (Eichler et al. 1993).

Effectiveness of aquatic herbicides is predictable and is therefore the most common form of controlling Eurasian watermilfoil in areas too large to hand pull. Moreover, herbicides are less expensive than diver-operated suction dredging and benthic barriers (Madsen 2000). Herbicides registered for use in the United States and permitted by the State of Michigan for Eurasian watermilfoil control are: 2,4-D, fluridone, endothall, and diquat. Success or failure of a herbicide treatment designed to control submersed plants depends upon the herbicide concentration that comes in contact with the target plant concomitant with the length of time a target plant is exposed to the dissipating herbicide concentration. Understanding this concentration exposure time (CET) relationship is critical in achieving desirable control of nuisance submersed plants (Getsinger and Netherland 1997). Each herbicide has different CET requirements, which dictate circumstances where it can be most effective. 
Diquat [6,7-dihydro-dipyrido (1,2-a:2',1'-c) pyrazinediium dibromide] is a contact herbicide that acts quickly to burn down plant foliage. Regrowth occurs within 6 to 8 weeks posttreatment. No CET relationships have been developed for diquat that would allow for its use as a method to selectively control Eurasian watermilfoil. When used at rates effective for controlling milfoil, diquat will also control other plants in the treated zone. Although it has a broad spectrum of activity, it may be used for effectively treating small plant beds or cleanup around docks, boat launches, and swimming areas. Broad spectrum removal of submersed aquatic plants in those settings would be seasonal and only represent a small proportion of the total plant community.

Endothall [7-oxabicyclo (2.2.1) heptane-2,3-dicarboxylic acid] is also a contact herbicide. Research of endothall CET relationships conducted at the ERDC have indicated that milfoil injury was directly proportional to the length of time plants were in contact with a given endothall concentration (Netherland et al. 1991). Control of Eurasian watermilfoil may last 8 weeks or longer. Endothall rates that are effective for milfoil control should have at least 18 - to 24-hour exposure times for best results (Netherland et al. 1991). Given these exposure times, water in treatment areas should be quiescent, with minimal flow. Small-scale research has shown that using low rates and exposure times of 1 to 3 days, endothall can be efficacious against Eurasian watermilfoil with minimal damage to nontarget vegetation (Skogerboe and Getsinger 2001, 2002).

Exposure times of 1 to 3 days are also required for control of Eurasian watermilfoil using the low-volatile butoxyethyl ester (BEE) of 2,4-D (2,4dichlorophenoxyacetic acid; Green and Westerdahl 1990). 2,4-D is a systemic herbicide and, once it is absorbed into plant tissues, shoots start to decay 7 to 14 days after application. Plants decompose slowly 14 to 28 days after application. Young, actively growing milfoil plants are more susceptible to 2,4-D than are mature, slowly growing plants. In cases where milfoil is not completely killed, regrowth can occur in 8 to 12 weeks following the initial application. Control of milfoil is selective at all rates, with minimal injury to nontarget plants (Getsinger et al. 1982; Parsons et al. 2001). 2,4-D has been routinely used to selectively control Eurasian watermilfoil in Michigan lakes and other Midwestern water bodies for many decades (Pullman 1992).

Triclopyr (3,5,6-trichloro-2-pyridinyloxyactetic acid) is a newly registered herbicide for aquatic uses. Similar to 2,4-D in its mode of action and translocation, this systemic herbicide is also effective against Eurasian watermilfoil requiring exposure times of 1 to 3 days (Netherland and Getsinger 1992). Stem epinasty and browning occurs 1 to 2 days after application, while plant decomposition occurs 14 to 28 days after application. Triclopyr is most efficacious against young, actively growing plants. Eurasian watermilfoil may be controlled for 3 years, including the year of treatment, with no adverse effects on native vegetation (Getsinger et al. 1997). Nonetheless, plant regrowth may occur in 4 to 6 weeks if Eurasian watermilfoil is not completely killed during herbicide application.

Fluridone (1-methyl-3-phenyl-5-[3-(trifluoromethyl)phenyl]-4(1H)pyridinone) is a systemic herbicide that requires a 45- to 60-day exposure time to be effective. Once the herbicide is absorbed by the plant leaves and stems, 
fluridone interrupts the carotenoid biosynthetic pathway; carotenoid pigments are necessary for plants to photosynthesize. Susceptible plants die and decompose slowly. If the treatment is effective, target plant regrowth usually does not occur for more than 12 months (Netherland and Getsinger 1993, 1995a, 1995b).

Although a broad-spectrum herbicide, it can be used to selectively control Eurasian watermilfoil with minimal damage to most native aquatic plants using low rates (Netherland et al. 1997; Getsinger et al. 2002).

A permit is required by the State of Michigan for all aquatic herbicide applications. There are special regulatory requirements regarding granular applications of endothall and 2,4-D. Currently, fluridone applications are restricted to spring applications with limits set on application rates. For complete use restrictions of any chemical product, refer to the product label. For permit and application restrictions contact the Michigan Department of Environmental Quality (MI-DEQ).

\section{Lake-Specific Vegetation Assessments}

This section presents results of detailed vegetation assessments on the 16 lakes surveyed in this study. Fourteen of the lakes are in Gogebic County, while two lakes, County Line and Tamarack, are on the border of another county, Ontonagon and Iron, respectively.

\section{Allen Lake}

Allen Lake has a surface area of 79 acres (Figure 5) and a mean water depth of $14 \mathrm{ft}$ (Table 1) with a maximum depth of $40 \mathrm{ft}$. The water was relatively clear with an MRD of $15 \mathrm{ft}$ (Table 5). About 30 percent of the lake has some vegetation based on survey data and 33 percent of plots that fell within the MRD (Table 2). The substrate was mostly hard bottom consisting of rock, gravel, or sand. The most common plants (Table 5) were floating leaf plants, Brasenia schreberi and Nymphaea odorata, and emergent plants including Dulichium arundinaceum, Equisetum fluviatile, and Sparganium species. Submersed plants occurred mostly in very shallow water and included small plants such as Eleocharis acicularis, Eriocaulon aquaticum, Juncus pelocarpus, Lobelia dortmanna, and Myriophyllum tenellum, which are indicative of relatively pristine systems based on their $\mathrm{CoC}$ rating. Allen Lake had a $\mathrm{CoC}_{\mathrm{avg}}$ rating of 6.9 and an $I$ of 26.7. Eurasian watermilfoil could become established in up to 33 percent of the lake based on the MRD. The substrate and plant species that occurred in the lake suggested that Eurasian watermilfoil may not reach nuisance levels with respect to recreation and aesthetics. Localized infestations, however, might significantly displace native submersed plant populations.

\section{Cisco Lake}

Cisco Lake (Figure 6) is part of the Cisco Chain of Lakes, and has a surface area of 500 acres and a mean depth of $11 \mathrm{ft}$ (Table 1) with a maximum depth of $20 \mathrm{ft}$. The water was relatively clear with an MRD of $14 \mathrm{ft}$ (Table 1). The lake is 


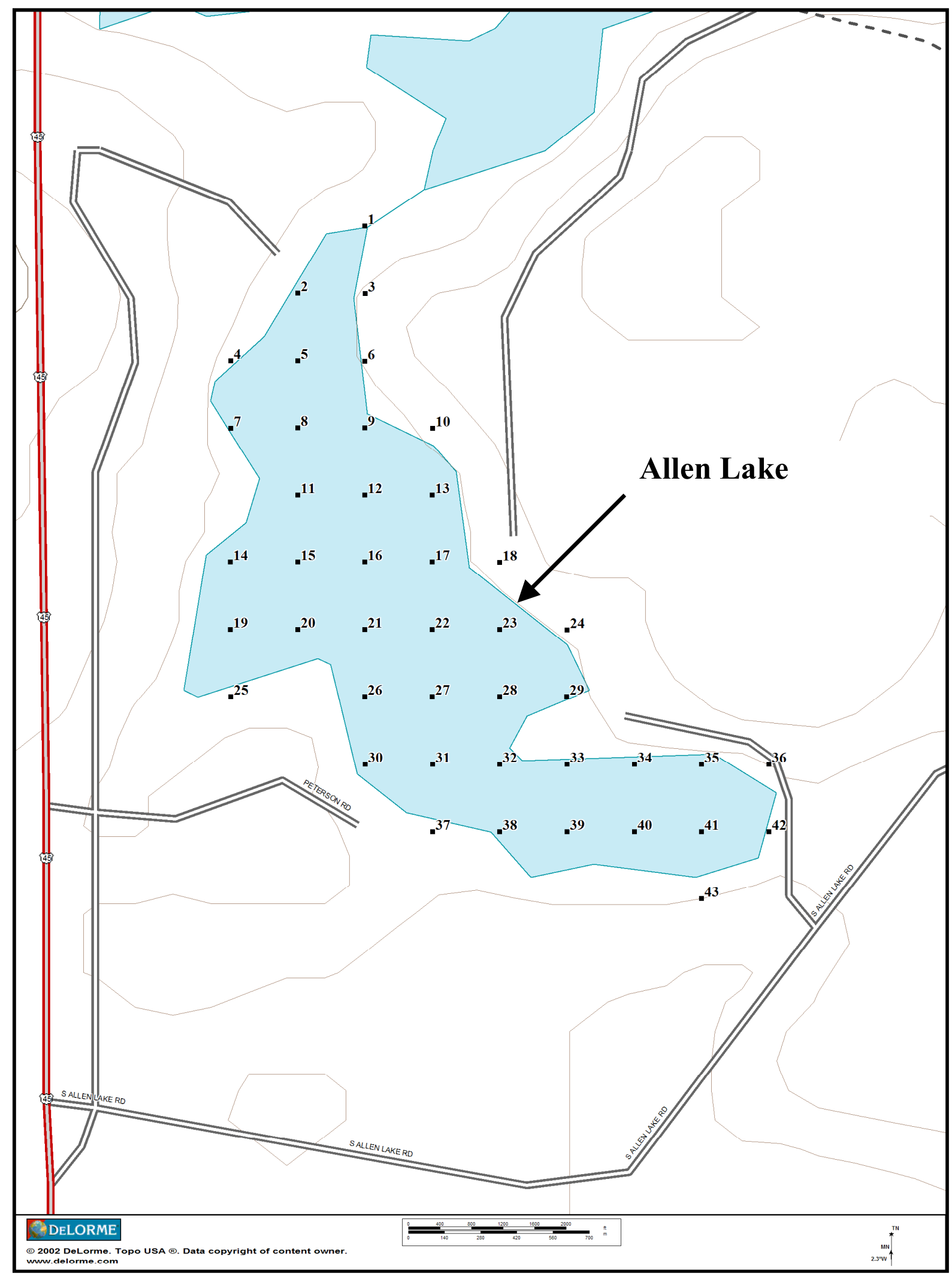

Figure 5. Allen Lake, Gogebic County, MI, aquatic plant survey locations - 2002. Squares on lake map indicate discrete GPS sampling points 


\begin{tabular}{|c|c|c|}
\hline \multicolumn{3}{|c|}{$\begin{array}{l}\text { Table } 5 \\
\text { Allen Lake, Gogebic County, MI, Aquatic Plant Survey Results - } \\
2002\end{array}$} \\
\hline Species & CoC Rating & $\%$ Occurrence \\
\hline Brasenia schreberi & 6 & 30.80 \\
\hline Dulichium arundinaceum & 9 & 26.90 \\
\hline Eleocharis acicularis & 5 & 3.90 \\
\hline Equisetum fluviatile & 7 & 11.50 \\
\hline Eriocaulon aquaticum & 9 & 11.50 \\
\hline Juncus pelocarpus & 8 & 3.90 \\
\hline Lemna triscula & 6 & 11.50 \\
\hline Lobelia dortmanna & 10 & 15.40 \\
\hline Myriophyllum tenellum & 10 & 19.20 \\
\hline Nuphar lutea ssp variegata & 6 & 7.70 \\
\hline Nymphaea odorata & 6 & 11.50 \\
\hline Sparganium augustfolium & 9 & 7.70 \\
\hline Sparganium eurycarpum & 5 & 3.90 \\
\hline Typha latifolia & 1 & 3.90 \\
\hline Utricularia vulgaris & 7 & 3.90 \\
\hline
\end{tabular}

connected by narrow channels and streams to numerous other lakes in the chain. Cisco Lake can be reached by boat from Clearwater Lake and Little Africa Lake, which were the sites of Eurasian watermilfoil infestations in 2001. About 60 percent of the lake has vegetation based on survey data, and 69 percent of sample locations fell within the MRD (Table 2). Numerous permanent and summer homes line the lakeshore. The substrate is mostly soft sediments with sufficient nutrients to support large stands of pondweeds including Potamogeton zosteriformis, P. robbinsii, P. richardsonii, and P. pusillus (Table 6). Other common submersed plants included Ceratophyllum demersum, Elodea canadensis, and Myriophyllum sibiricum. Overall, Cisco Lake had an I of 32.1 and a $\mathrm{CoC}_{\mathrm{avg}}$ rating of 6.6. Eurasian watermilfoil could become established in up to 69 percent of the lake based on the MRD. The substrate and plant species that occurred in the lake indicated that Eurasian watermilfoil might reach nuisance levels with respect to recreation and aesthetics. Infestations also might adversely impact native submersed plant populations. Once established in Cisco Lake, Eurasian watermilfoil could quickly spread to other lakes in the Cisco Chain of Lakes via boat traffic, water currents, and animals.

\section{Clearwater Lake}

Clearwater Lake (Figure 7) is part of the Cisco Chain of Lakes and has a surface area of 170 acres with a mean depth of $7 \mathrm{ft}$ (Table 1) with a maximum of $20 \mathrm{ft}$. The water was relatively clear with an MRD of $11 \mathrm{ft}$ (Table 1). The lake is connected to numerous other lakes in the chain by streams that flow into Little Africa Lake, then Big Africa Lake, and finally into Thousand Island Lake. 


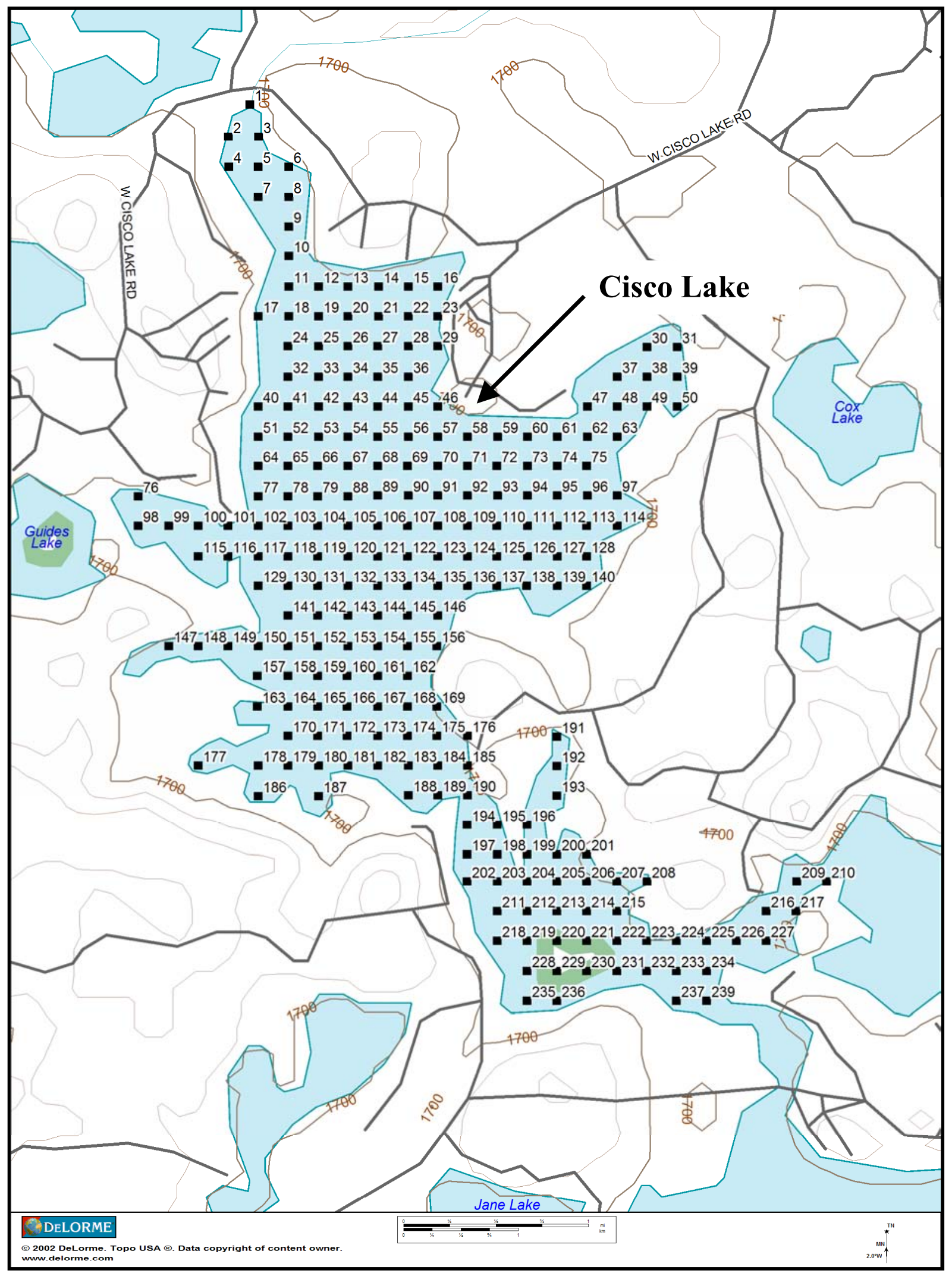

Figure 6. Cisco Lake, Gogebic County, MI, aquatic plant survey locations -2002 . Squares on lake map indicate discrete GPS sampling points 


\begin{tabular}{|l|l|l||}
\hline $\begin{array}{l}\text { Table 6 } \\
\text { Cisco Lake, Gogebic County, MI, Aquatic Plant Survey Results - } \\
2002\end{array}$ & CoC Rating \\
\hline \hline Species & 6 & $\%$ Occurrence \\
\hline \hline Brasenia schreberi & 6 & 3.13 \\
\hline Ceratophyllum demersum & 3 & 36.50 \\
\hline Chara spp & & 1.04 \\
\hline Elodea canadensis & 6 & 14.58 \\
\hline Lemna triscula & 6 & 4.17 \\
\hline Megalodonta beckii & 8 & 3.13 \\
\hline Myriophyllum sibiricum & 6 & 18.75 \\
\hline Najas flexilis & 6 & 4.17 \\
\hline Nuphar lutea ssp variegata & 8 & 11.46 \\
\hline Nymphaea odorata & 6 & 14.58 \\
\hline Pontedaria cordata & 8 & 2.08 \\
\hline Potamogeton amplifolius & 7 & 7.29 \\
\hline Potamogeton epihydrus & 8 & 6.25 \\
\hline Potamogeton gramineus & 7 & 1.04 \\
\hline Potamogeton pusillus & 7 & 12.5 \\
\hline Potamogeton richardsonii & 5 & 27.08 \\
\hline Potamogeton robbinsii & 8 & 42.71 \\
\hline Potamogeton zosteriformis & 6 & 50.00 \\
\hline Ranunculus longirostris & 8 & 2.08 \\
\hline Sparganium augustifolium & 9 & 3.13 \\
\hline Sparganium eurycarpum & 5 & 2.08 \\
\hline Utricularia microrhiza & 7 & 5.21 \\
\hline Vallisneria americana & 6 & 9.38 \\
\hline \hline
\end{tabular}

About 70 percent of the lake has some vegetation based on survey data and 83 percent of sample locations fell within the MRD (Table 2). Numerous permanent and summer homes line the northern and western lakeshore. The southern and eastern shores were mostly forested land managed by the USFS. The substrate consisted of soft sediments with sufficient nutrients to support large stands of pondweeds (Table 7) including Potamogeton gramineus, $P$. richardsonii, and $P$. amplifolius. The most common plant was Vallisneria americana, and other common plants included Utricularia vulgaris and small Isoetes species. Overall, Clearwater Lake had a $\mathrm{CoC}_{\mathrm{avg}}$ rating of 6.7 with 21 different species and an $I$ of 31.4 .

Clearwater Lake is the site of the first reported Eurasian watermilfoil infestation in the region, where 55 acres of the plant occurred in 2000 (L. Esman, MI-DEQ, pers. comm.). The following year, all infested areas were treated with the aquatic herbicide, 2,4-D. In 2002 no Eurasian watermilfoil was found at any of the sample locations or by visual observation while traversing from one sample point to another. Eurasian watermilfoil could become established in up to 


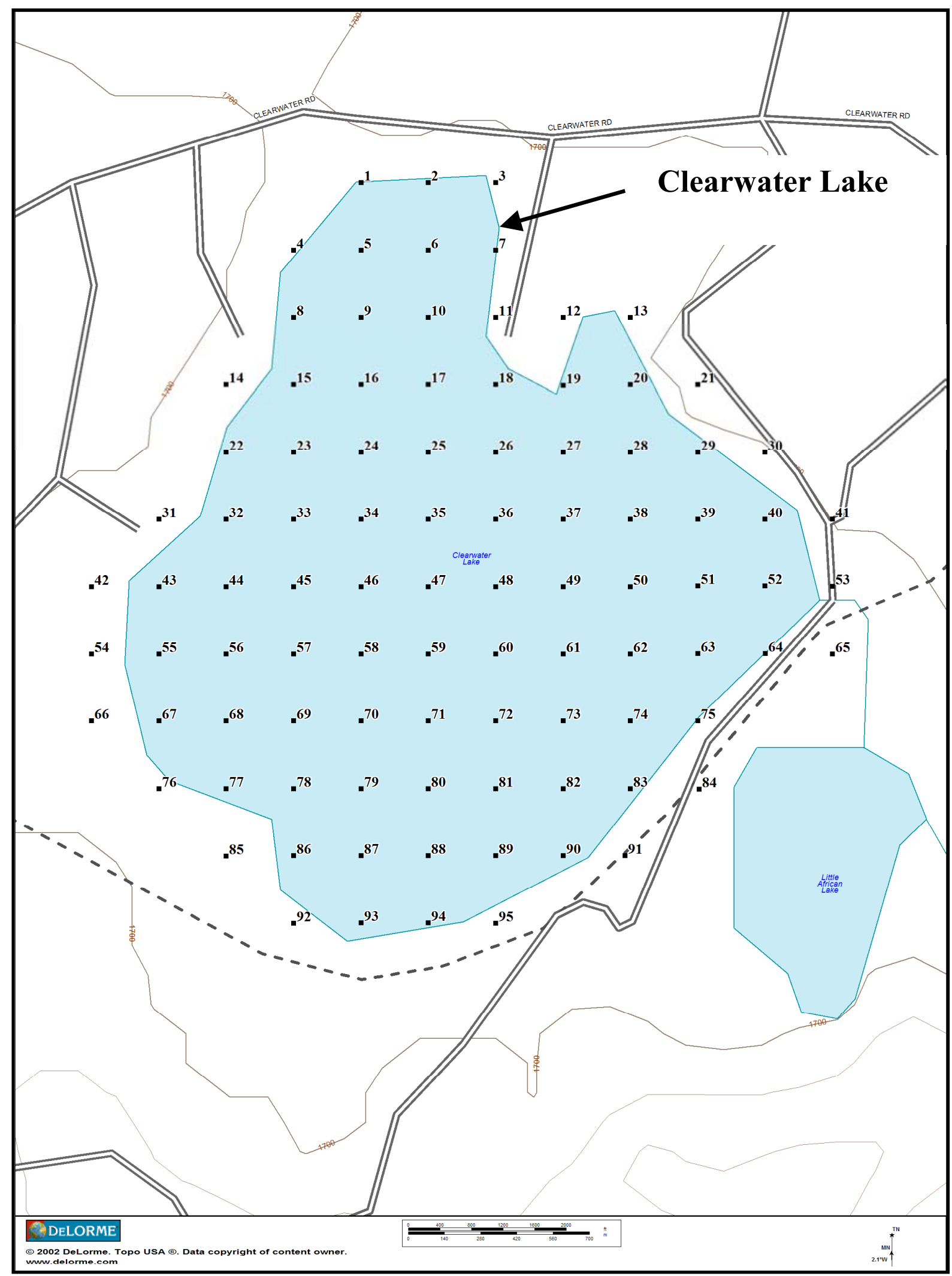

Figure 7. Clearwater Lake, Gogebic County, MI, aquatic plant survey locations -2002 . Squares on lake map indicate discrete GPS sampling points 


\begin{tabular}{|c|c|c|}
\hline \multicolumn{3}{|c|}{$\begin{array}{l}\text { Table } 7 \\
\text { Clearwater Lake, Gogebic County, MI, Aquatic Plant Survey } \\
\text { Results - } 2002\end{array}$} \\
\hline Species & CoC Rating & $\%$ Occurrence \\
\hline Brasenia schreberi & 6 & 1.41 \\
\hline Ceratophyllum demersum & 3 & 1.41 \\
\hline Chara spp & & 14.08 \\
\hline Eleocharis acicularis & 5 & 7.04 \\
\hline Elodea canadensis & 6 & 2.82 \\
\hline Equisetum fluviatile & 7 & 4.23 \\
\hline Eriocaulon aquaticum & 9 & 2.82 \\
\hline Isoetes lacustris & 8 & 15.49 \\
\hline Lobelia dortmanna & 10 & 7.04 \\
\hline Myriophyllum tenellum & 10 & 4.23 \\
\hline Nuphar lutea ssp variegata & 6 & 8.45 \\
\hline Nymphaea odorata & 6 & 4.23 \\
\hline Pontedaria cordata & 8 & 9.86 \\
\hline Potamogeton amplifolius & 7 & 15.49 \\
\hline Potamogeton gramineus & 7 & 26.76 \\
\hline Potamogeton richardsonii & 5 & 19.72 \\
\hline Ranunculus flammula & 9 & 4.23 \\
\hline Sparganium augustifolium & 9 & 4.23 \\
\hline Typha latifolia & 1 & 2.82 \\
\hline Utricularia vulgaris & 7 & 21.13 \\
\hline Vallisneria americana & 6 & 36.62 \\
\hline
\end{tabular}

83 percent of the lake based on the MRD. The substrate and plant species that occur in the lake indicated that Eurasian watermilfoil might reach nuisance levels, impacting recreation and aesthetics. Infestations also might adversely impact native submersed plant populations. Once established in Clearwater Lake, Eurasian watermilfoil could quickly spread to other lakes in the Cisco Chain of Lakes via boat traffic, currents, and animals, as was the case when it was found downstream in Little Africa Lake in 2000.

\section{County Line Lake}

County Line Lake has a surface area of 72 acres (Figure 8), a mean water depth of $20 \mathrm{ft}$ (Table 1), and a maximum depth of $65 \mathrm{ft}$. The water was relatively clear with an MRD of $18 \mathrm{ft}$ (Table 1). Only about 30 percent of the lake has some vegetation based on survey data even though 54 percent of sample points fell within the MRD (Table 2). The substrate was mostly hard bottom consisting of rock, gravel, or sand. The most common plant (Table 8) was the floating leaf plant, Brasenia schreberi, and emergent Sparganium spp. Submersed species occurred near the shoreline, and included such small plants as Elatine minima, Eleocharis acicularis, and Eriocaulon aquaticum. These plants indicate relatively pristine systems based on their $\mathrm{CoC}$ rating. The total number of species 


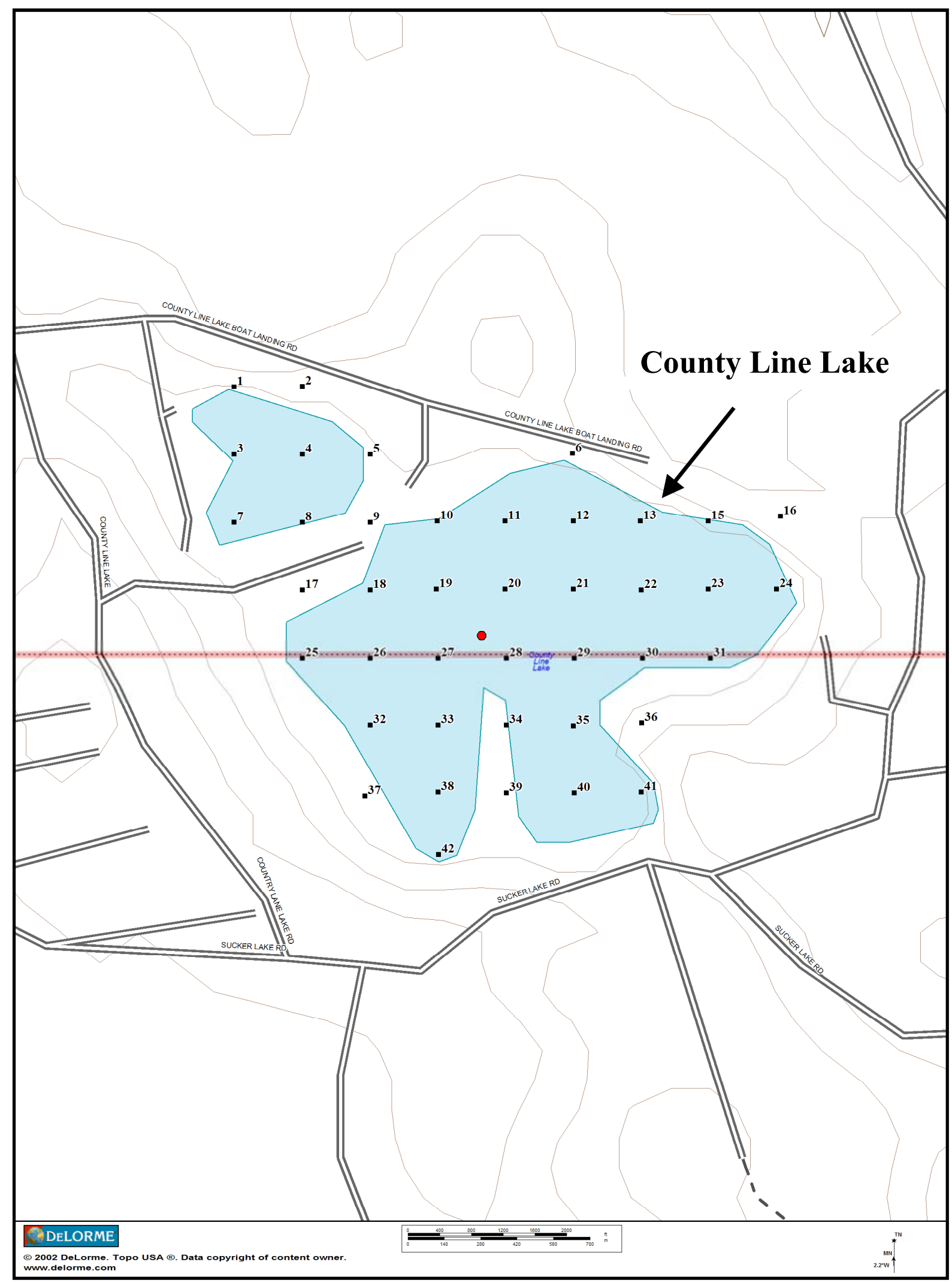

Figure 8. County Line Lake, Gogebic County, MI, aquatic plant survey locations - 2002. Squares on lake map indicate discrete GPS sampling points 


\begin{tabular}{|c|c|c|}
\hline \multicolumn{3}{|c|}{$\begin{array}{l}\text { Table } 8 \\
\text { County Line Lake, Gogebic County, MI, Aquatic Plant Survey } \\
\text { Results - } 2002\end{array}$} \\
\hline Species & CoC Rating & $\%$ Occurrence \\
\hline Brasenia schreberi & 6 & 50.00 \\
\hline Elatine minima & 9 & 4.55 \\
\hline Eleocharis acicularis & 5 & 9.09 \\
\hline Eriocaulon aquaticum & 9 & 9.09 \\
\hline Nuphar lutea ssp variegata & 8 & 4.55 \\
\hline Sparganium augustifolium & 9 & 9.09 \\
\hline Sparganium chlorocarpum & 8 & 13.64 \\
\hline
\end{tabular}

was low (7) with an $I$ of 19.6 , but the $\mathrm{CoC}_{\text {avg }}$ rating of 7.7 was one of the highest for the lakes surveyed in this study. Eurasian watermilfoil could become established in up to 54 percent of the lake based on the MRD. The substrate and plant species that occurred in the lake indicated that Eurasian watermilfoil may not reach nuisance levels with respect to recreation and aesthetics. Localized infestations, however, could significantly displace native submersed plant populations.

\section{Crooked Lake}

Crooked Lake is part of the USFS SWA. A small section in the northernmost bay is privately owned and includes a resort. Although residents and resort guests are allowed to use motorized boats on the lake, boat motor use by the public is prohibited. The lake is not directly connected to other lakes within the SWA, but overland trails are maintained to allow portaging of boats to other lakes. The surface area of Crooked Lake is 566 acres (Figure 9) with a mean depth of $15 \mathrm{ft}$ (Table 1) and a maximum depth of $66 \mathrm{ft}$. The water in the lake was very clear with an MRD of $26 \mathrm{ft}$ (Table 1). About 56 percent of the lake has some vegetation based on survey data, and 87 percent of sample locations fell within the MRD (Table 2). Much of the substrate contained sufficient nutrients to support large stands of pondweeds (Table 9) including Potamogeton zosteriformis, $P$. robbinsii, $P$. richardsonii, and $P$. gramineus. A total of 28 species were collected; the $\mathrm{CoC}_{\text {avg }}$ rating was 6.5 with an $I$ of 33.8. A large stand of Zizania aquatica was found in the southeast bay.

A very small infestation of Eurasian watermilfoil was found near the USFS boat ramp in the northern bay (Figure 9). Five individual plants were found at the site and removed by hand pulling. These samples were destroyed. Although the infestation was controlled, this site should be carefully monitored to ensure that hand-pulling efforts were effective. If more plants are found, the Eurasian watermilfoil should be controlled using aquatic herbicides to prevent spread by boat traffic and animals to other lakes near the SWA. Based on the MRD, Eurasian watermilfoil could become established in up to 69 percent of the lake, which would severely impact recreation and aesthetics and displace native submersed plant populations. 


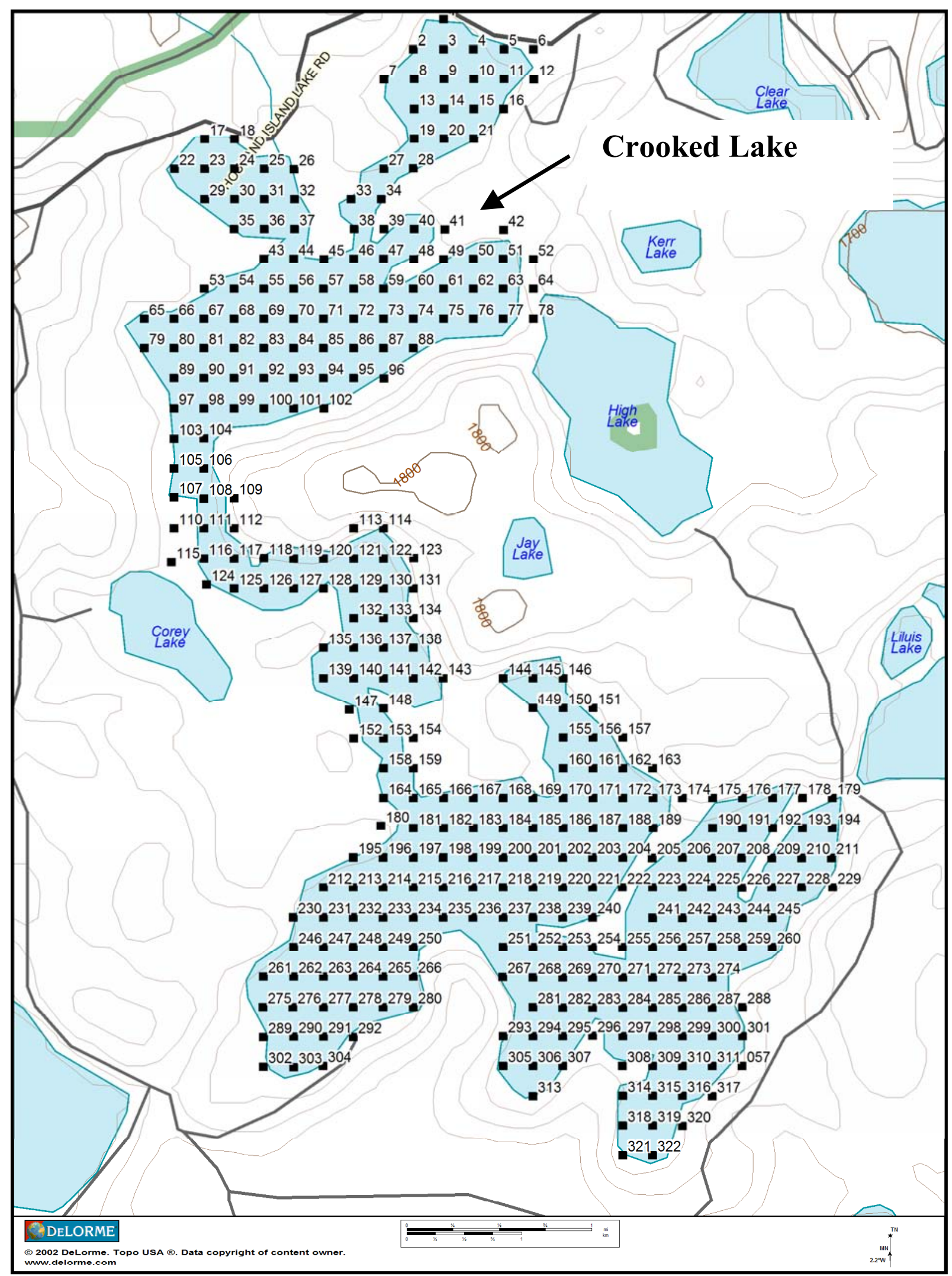

Figure 9. Crooked Lake, Gogebic County, MI, aquatic plant survey locations - 2002. Squares on lake map indicate discrete GPS sampling points 


\begin{tabular}{|c|c|c|}
\hline \multicolumn{3}{|c|}{$\begin{array}{l}\text { Table } 9 \\
\text { Crooked Lake, Gogebic County, MI, Aquatic Plant Survey Results - } \\
2002\end{array}$} \\
\hline Species & CoC Rating & $\%$ Occurrence \\
\hline Brasenia schreberi & 6 & 0.42 \\
\hline Ceratophyllum demersum & 3 & 0.42 \\
\hline Chara spp & & 1.67 \\
\hline Eleocharis acicularis & 5 & 0.42 \\
\hline Elodea canadensis & 6 & 9.62 \\
\hline Iris versicolor & 5 & 2.09 \\
\hline Lemna triscula & 6 & 0.84 \\
\hline Megalodonta beckii & 8 & 1.67 \\
\hline Myriophyllum sibiricum & 6 & 3.77 \\
\hline Myriophyllum spicatum & & 0.42 \\
\hline Myriophyllum farwellii & 8 & 0.42 \\
\hline Najas flexilis & 6 & 9.62 \\
\hline Nuphar lutea ssp variegata & 8 & 5.02 \\
\hline Nymphaea odorata & 6 & 4.18 \\
\hline Pontedaria cordata & 8 & 0.42 \\
\hline Polygonum amphibium & 5 & 7.95 \\
\hline Potamogeton epihydrus & 8 & 5.02 \\
\hline Potamogeton gramineus & 7 & 4.60 \\
\hline Potamogeton natans & 5 & 2.51 \\
\hline Potamogeton pusillus & 7 & 17.99 \\
\hline Potamogeton richardsonii & 5 & 17.15 \\
\hline Potamogeton robbinsii & 8 & 22.59 \\
\hline Potamogeton zosteriformis & 6 & 29.29 \\
\hline Sagittaria graminea var. cristata & 9 & 2.09 \\
\hline Sparganium augustifolium & 10 & 0.42 \\
\hline Vallisneria americana & 6 & 4.60 \\
\hline Zizania aquatica & 8 & 7.11 \\
\hline Zosterella dubia & 6 & 1.67 \\
\hline
\end{tabular}

\section{Dinner Lake}

Dinner Lake has a surface area of 106 acres (Figure 10) and a mean water depth of $11 \mathrm{ft}$ (Table 1) with a maximum depth of $25 \mathrm{ft}$. The water was relatively clear with an MRD of $19 \mathrm{ft}$ (Table 1). Although 90 percent of sample points fell within the MRD, only about 34 percent of the lake has some vegetation based on survey data (Table 2). The substrate was mostly hard bottom consisting of rock, gravel, or sand, and may have prevented the colonization of a larger plant community. The most common species was the floating leaf plant, Nymphaea odorata (Table 10). Common submersed plant species included Vallisneria americana and Sagittaria graminea. Submersed species occurred mostly in very 


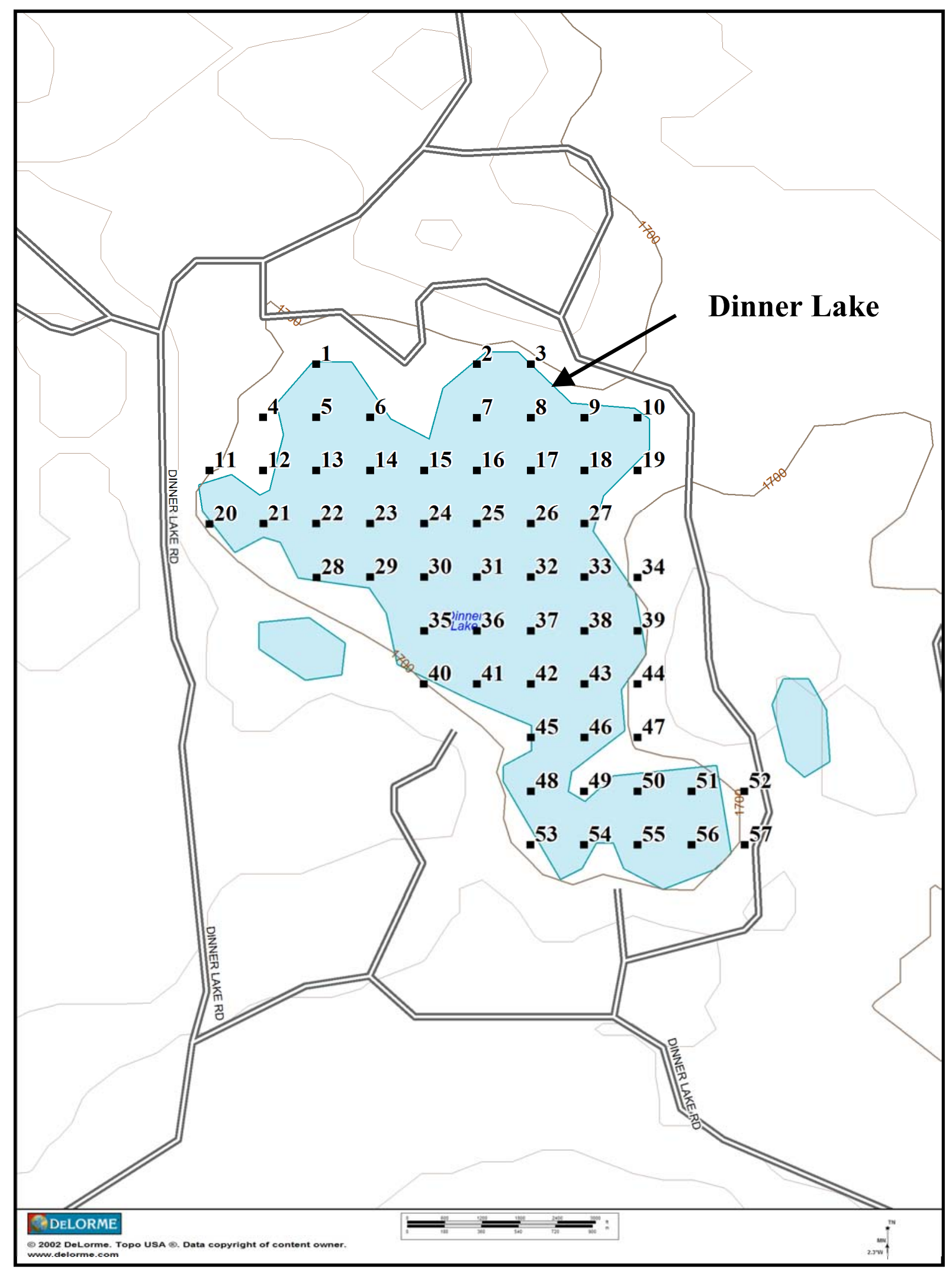

Figure 10. Dinner Lake, Gogebic County, MI, aquatic plant survey locations -2002 . Squares on lake map indicate discrete GPS sampling points 


\begin{tabular}{|c|c|c|}
\hline \multicolumn{3}{|c|}{$\begin{array}{l}\text { Table } 10 \\
\text { Dinner Lake, Gogebic County, MI, Aquatic Plant Survey Results - } \\
2002\end{array}$} \\
\hline Species & CoC Rating & $\%$ Occurrence \\
\hline Chara spp & & 8.89 \\
\hline Eleocharis acicularis & 5 & 4.44 \\
\hline Elodea canadensis & 6 & 6.67 \\
\hline Iris versicolor & 5 & 8.89 \\
\hline Isoetes lacustris & 8 & 2.22 \\
\hline Lemna triscula & 6 & 2.22 \\
\hline Nuphar lutea ssp variegata & 8 & 2.22 \\
\hline Nymphaea odorata & 6 & 22.22 \\
\hline Potamogeton epihydrus & 8 & 4.44 \\
\hline Potamogeton foliosus & 6 & 4.44 \\
\hline Potamogeton richardsonii & 5 & 4.44 \\
\hline Potamogeton robbinsii & 8 & 2.22 \\
\hline Ranunculus flammula & 9 & 2.22 \\
\hline Sagittaria graminea var. cristata & 9 & 11.11 \\
\hline Vallisneria americana & 6 & 11.11 \\
\hline
\end{tabular}

shallow water and included small plants such as Elatine minima, Eleocharis acicularis, and Eriocaulon aquaticum, which are indicative of relatively pristine systems based on their $\mathrm{CoC}$ rating. A number of pondweeds were found, but were uncommon. The total number of species was 14 with a $\mathrm{CoC}_{\mathrm{avg}}$ of 6.6 and an $I$ of 25.9. Although Eurasian watermilfoil could become established in up to 90 percent of the lake based on the MRD, the substrate and plant survey data indicated that Eurasian watermilfoil might not reach these levels. Localized infestations, however, could have significant adverse effects on native submersed plant populations.

\section{Duck Lake}

Duck Lake has a surface area of 610 acres (Figure 11), a maximum water depth of $25 \mathrm{ft}$, and a mean depth of $7 \mathrm{ft}$ (Table 1). A sizable island is located in the west central part of the lake. The shoreline is mostly developed, although houses are typically on large lots leaving considerable amounts of undisturbed lakeshore. The water was relatively clear with an MRD of $15 \mathrm{ft}$ (Table 1). A small creek flows into the north end of the lake. The area around the inlet had a soft organic substrate with depths within the MRD. Otherwise, the northern half of the lake east and north of the island was deeper than the MRD, except for a narrow band along the shoreline before a generally steep drop-off to deeper water. A shallow heavily vegetated area within the MRD occurred between the island and the west shore. The outlet of the lake, Duck Creek, is at the southern end of the lake. The southern one-third of the lake had a gradually sloping to level, mostly organic bottom that is within the MRD. Based on the MRD, Eurasian watermilfoil could colonize 47 percent of the lake. About 44 percent 


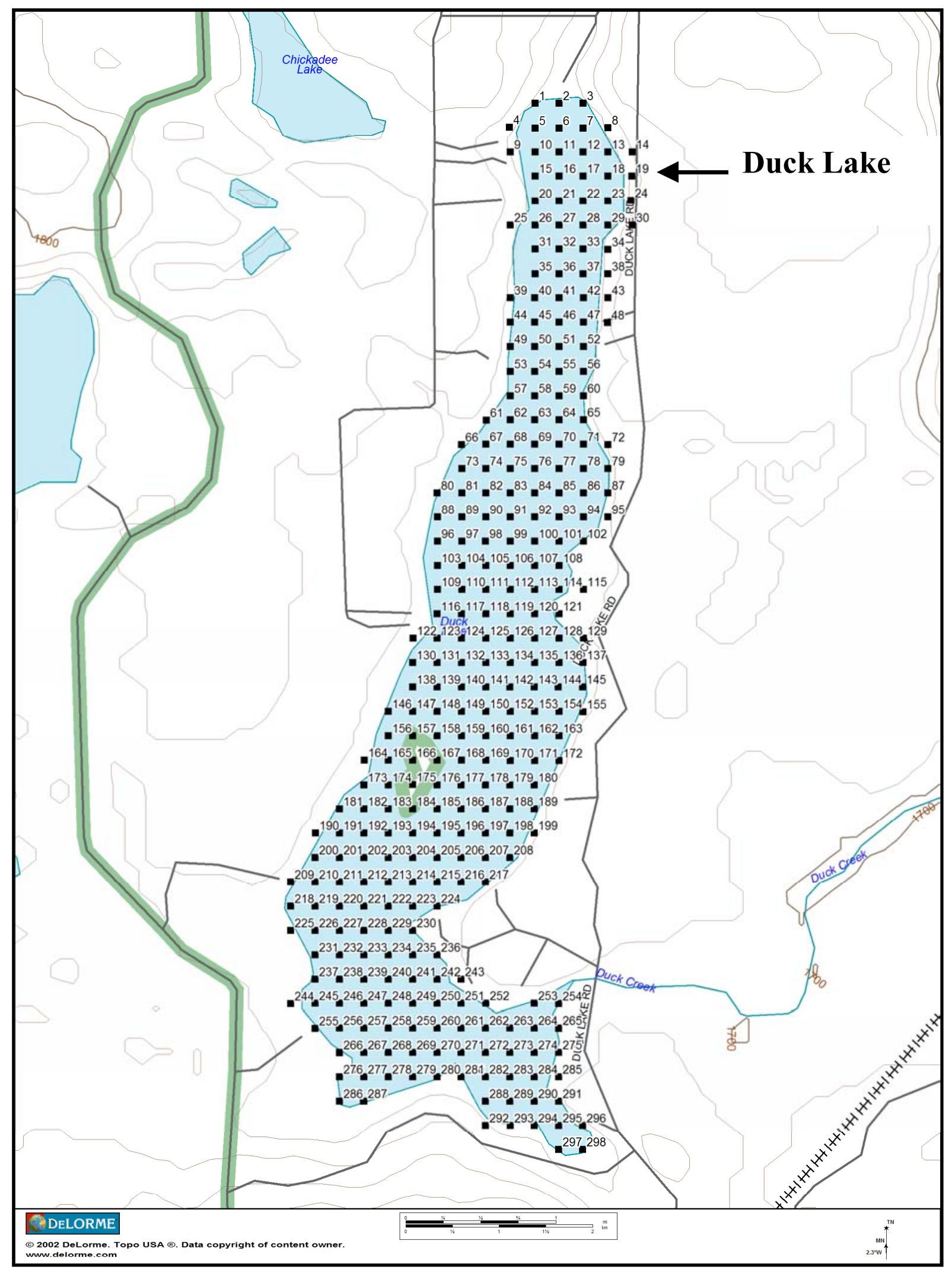

Figure 11. Duck Lake, Gogebic County, MI, aquatic plant survey locations - 2002. Squares on lake map indicate discrete GPS sampling points 


\begin{tabular}{|c|c|c|}
\hline \multicolumn{3}{|c|}{$\begin{array}{l}\text { Table } 11 \\
\text { Duck Lake, Gogebic County, MI, Aquatic Plant Survey Results - } \\
2002\end{array}$} \\
\hline Species & CoC Rating & $\%$ Occurrence \\
\hline Brasenia schreberi & 6 & 2.59 \\
\hline Carex lasiocarpa & 9 & Present \\
\hline Dulichium arundinaceum & 9 & 0.86 \\
\hline Eleocharis acicularis & 5 & 4.31 \\
\hline Eleocharis smallii & 6 & 4.31 \\
\hline Elodea Canadensis & 6 & 50.86 \\
\hline Equisetum fluviatile & 7 & Present \\
\hline Isoetes lacustris & 8 & 0.86 \\
\hline Isoetes echinospora & 8 & 2.59 \\
\hline Isoetes spp & 8 & 2.59 \\
\hline Juncus pelocarpus & 8 & 4.31 \\
\hline Lobelia dortmanna & 10 & 5.17 \\
\hline Myriophyllum sibiricum & 6 & 3.45 \\
\hline Myriophyllum tenellum & 10 & 10.34 \\
\hline Najas flexilis & 6 & 4.31 \\
\hline Nuphar lutea ssp variegata & 6 & Present \\
\hline Nymphaea odorata & 6 & 1.72 \\
\hline Phragmites australis & 1 & 0.86 \\
\hline Potamogeton alpinus & 9 & 0.86 \\
\hline Potamogeton amplifolius & 7 & 55.17 \\
\hline Potamogeton epihydrus & 8 & 6.03 \\
\hline Potamogeton gramineus & 7 & 26.72 \\
\hline Potamogeton natans & 5 & 2.59 \\
\hline Potamogeton pusillus ssp tenuissimus & 7 & 7.76 \\
\hline Potamogeton robbinsii & 8 & 38.79 \\
\hline Potamogeton spirillus & 8 & 0.86 \\
\hline Rannuculus flammula var. filiformis & 9 & 3.45 \\
\hline Sagittaria graminea & 9 & 0.86 \\
\hline Scirpus acutus & 6 & 2.59 \\
\hline Utricularia vulgaris & 7 & 0.86 \\
\hline Vallisneria Americana & 6 & 17.24 \\
\hline
\end{tabular}

of the lake had some vegetation based on the number of points that fell within the MRD (Table 2). Shallow organic bottom bays in the southern end of the lake were covered with floating vegetation (Table 11) consisting of Brasenia schreberi and Potamogeton natans on the surface with Elodea canadensis, Potamogeton amplifolius, and P. robbinsii most common beneath. Deeper areas in the lake were dominated by Elodea canadensis, $P$. amplifolius, and $P$. robbinsii, with $P$. gramineus and Vallisneria americana also common. Lobelia dortmanna, Myriophyllum tenellum, Juncus pelocarpus, Eleocharis acicularis, Najas flexilis, and Isoetes species made up the typical vegetation community in shallow areas with a hard bottom. These areas also had Scirpus acutus and Eleocharis smallii as typical emergents. P. amplifolius, Elodea canadensis, $P$. robbinsii, and $P$. gramineus were the most common aquatic plants occurring on 55, 51, 39, and 27 percent of all points respectively. The $\mathrm{CoC}_{\mathrm{avg}}$ rating of the lake was 7.1 and the $I$ was 39.5 . 


\section{Imp Lake}

Imp Lake has a surface area of 74 acres (Figure 12) and a mean depth of $39 \mathrm{ft}$ (Table 1) with a maximum depth of $80 \mathrm{ft}$. The water was very clear with an MRD of $29 \mathrm{ft}$ (Table 1). The substrate was mostly hard bottom consisting of rock, gravel, or sand. Much of the lake is very deep, and the deepest point is greater than $90 \mathrm{ft}$. Only about 14 percent of the lake has some vegetation based on survey data and 30 percent of sample points fell within the MRD (Table 2). The most common species were the floating leaf plants, Nuphar lutea ssp variegata and Nymphae odorata, and emergent plants, Sparganium augustifolium, Juncus pelocarpus, J. effusus, Elatine minima, and Glyceria borealis (Table 12). The total number of plant species was low (11), and the number of submersed species was only 2, Eriocaulon aquaticum and Potamogeton epihydrus. The $\mathrm{CoC}_{\mathrm{avg}}$ rating of 7.9 was one of the highest for the lakes surveyed, and the $I$ was 27.4. Eurasian watermilfoil could become established in up to 30 percent of the lake based on the MRD. The substrate and plant species that occurred in the lake indicated that Eurasian watermilfoil might not reach nuisance levels. Localized infestations, however, could significantly displace native submersed plant populations.

\section{Langford Lake}

The surface area of Langford Lake is 476 acres (Figure 13) with a mean depth of $8 \mathrm{ft}$ (Table 1). The water in the lake was very clear with an MRD of $26 \mathrm{ft}$ (Table 1). The lakeshore consists partly of permanent and summer lake homes, and the remainder is a portion of the Ottawa National Forest. The public boat ramp and campground on the northeast side of the lake is managed by the USFS. About 46 percent of the lake has some vegetation based on survey data, and 65 percent of sample locations fell within the MRD (Table 2). Much of the substrate is soft sediments with sufficient nutrients to support large stands of pondweeds (Table 13) including Potamogeton amplifolius, P. gramineus, $P$. richardsonii, $P$. robbinsii, and $P$. zosteriformis. A total of 31 species were collected, which was the most for any lake surveyed, and the $I$ was 37.1. The $\mathrm{CoC}_{\text {avg }}$ rating was 6.8. Eurasian watermilfoil was found near the USFS boat ramp on the west side of the bay (Figure 13), scattered in a 100-yd strip in front of the ramp and campground out to about $20 \mathrm{yd}$ from shore. Eurasian watermilfoil could become established in up to 65 percent of the lake based on the MRD. The substrate and plant species that occur in the lake indicate that Eurasian watermilfoil could reach nuisance levels with respect to recreation and aesthetics. Infestations could also have significant adverse impacts on the submersed plant populations. Once established in Langford Lake, Eurasian watermilfoil could spread to other lakes in the area via boat traffic, the outflow stream, and animals. The present infestation is very small, but is probably too large to be controlled effectively by SCUBA divers and hand-pulling techniques. Therefore, the infested area should be treated as soon as possible with an approved aquatic herbicide. The site should then be carefully monitored to ensure that the herbicide application was effective. In many cases, a second herbicide application or more hand pulling may be necessary to eradicate the infestation. 


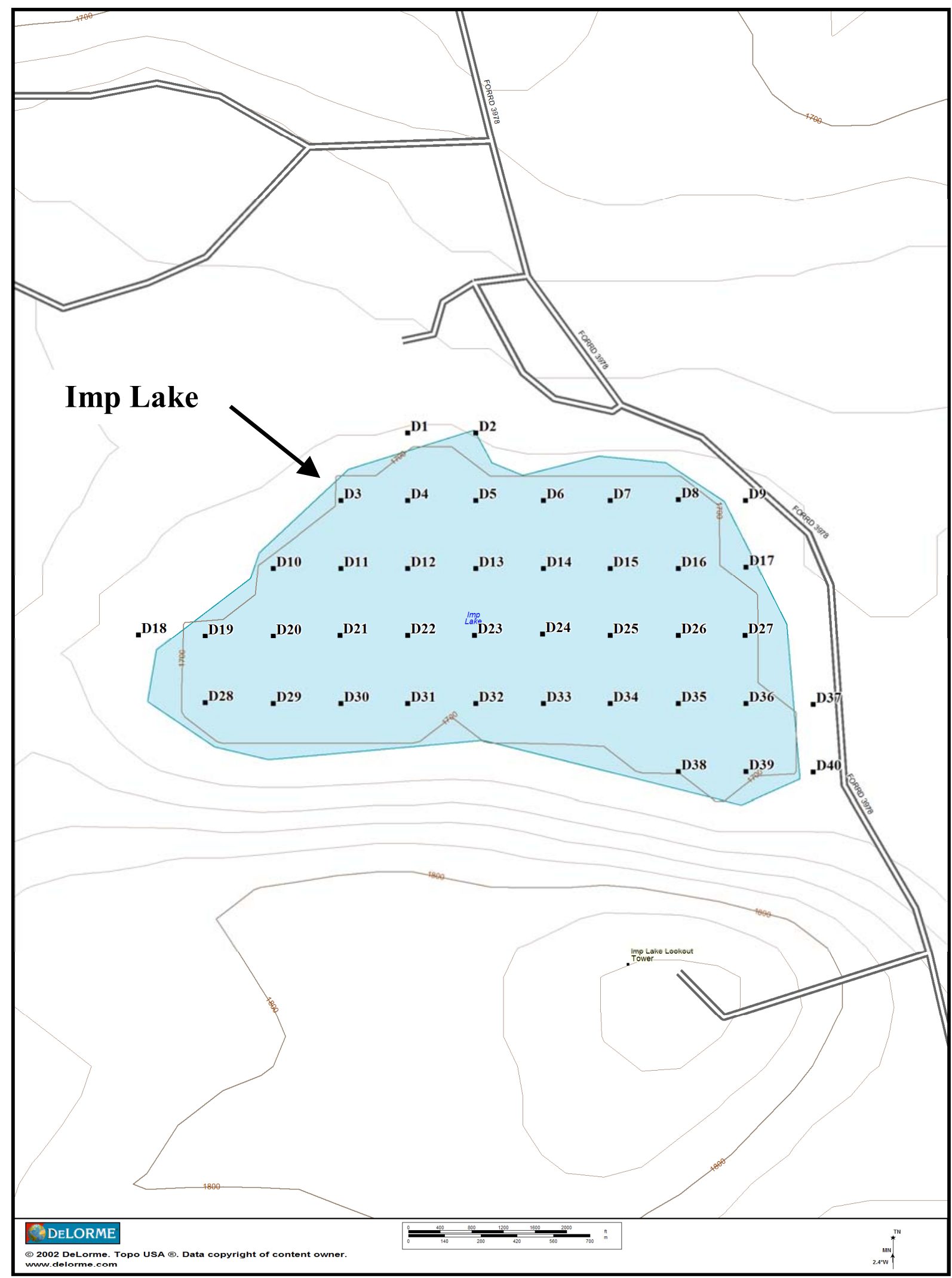

Figure 12. Imp Lake, Gogebic County, MI, aquatic plant survey locations - 2002. Squares on lake map indicate discrete GPS sampling points 


\begin{tabular}{|l|l|l||}
\hline $\begin{array}{l}\text { Table 12 } \\
\text { Imp Lake, Gogebic County, MI, Aquatic Plant Survey Results - 2002 }\end{array}$ \\
\hline \hline Species & CoC Rating & \% Occurrence \\
\hline \hline Dulichium arundinaceum & 9 & 6.67 \\
\hline Elatine minima & 9 & 13.33 \\
\hline Eriocaulon aquaticum & 9 & 6.67 \\
\hline Glyceria borealis & 8 & 13.33 \\
\hline Juncus effuses & 4 & 13.33 \\
\hline Juncus pelocarpus & 8 & 33.33 \\
\hline Lobelia dortmanna & 10 & 6.67 \\
\hline Nuphar lutea ssp variegata & 6 & 6.67 \\
\hline Nymphaea odorata & 6 & 6.67 \\
\hline Potamogeton epihydrus & 8 & 6.67 \\
\hline Sparganium augustifolium & 9 & 26.67 \\
\hline Utricularia resupinata & 9 & 6.67 \\
\hline
\end{tabular}

\section{Little Africa Lake}

Little Africa Lake is part of the Cisco Chain of Lakes. The lake is between Clearwater and Big Africa Lakes and is connected to both by a stream. The surface area is 18 acres (Figure 14), with a mean depth of $7 \mathrm{ft}$ (Table 1). The MRD of the lake is $9 \mathrm{ft}$ (Table 1). Little Africa Lake does not have a public access boat ramp; however, a small infestation of Eurasian watermilfoil occurred in 2000, probably transported to the site by the stream flowing in from Clearwater Lake. An area of less than 1 acre was treated with the aquatic herbicide 2,4-D in summer 2001. About 58 percent of the lake has some vegetation based on survey data, and 58 percent of sample locations fell within the MRD (Table 2). No homes were built along the lake. The substrate consisted mostly of soft sediments with sufficient nutrients to support large stands of pondweeds (Table 14) including Potamogeton amplifolius, $P$. epihydrus, $P$. richardsonii, P. robbinsii, and Stuckenia pectinata. Other common species included the floating leaf plants, Nuphar lutea ssp variegata, Nymphaea, and Brasenia schreberi, emergent plants including Pontedaria cordata and Sparganium augustifolium. Utricularia vulgaris and Ceratophyllum demersum were also common. Little Africa Lake had a $\mathrm{CoC}_{\text {avg }}$ rating of 6.7 and an $I$ of 23.9. No Eurasian watermilfoil was found at any of the sample locations or by visual observation while traversing from one sample point to another. Eurasian watermilfoil could become established in up to 58 percent of the lake based on the MRD and plant survey data. The substrate and plant species that occur in the lake indicate that Eurasian watermilfoil could reach nuisance levels with respect to recreation and aesthetics. Infestations could also have significant adverse impacts on the submersed plant populations. Once established in Little Africa Lake, Eurasian watermilfoil could quickly spread to other lakes in the Cisco Chain of Lakes via boat traffic, water currents, and animals as was the case when Eurasian watermilfoil was found downstream from Clearwater Lake, in Little Africa Lake in 2000, and in Big Africa Lake in 2002. The herbicide application conducted in summer 2001 was very effective. No Eurasian watermilfoil was found in Little Africa Lake in summer 2002, but the lake continued to support native aquatic plants, including 13 different species, at 58 percent of the sample locations. 


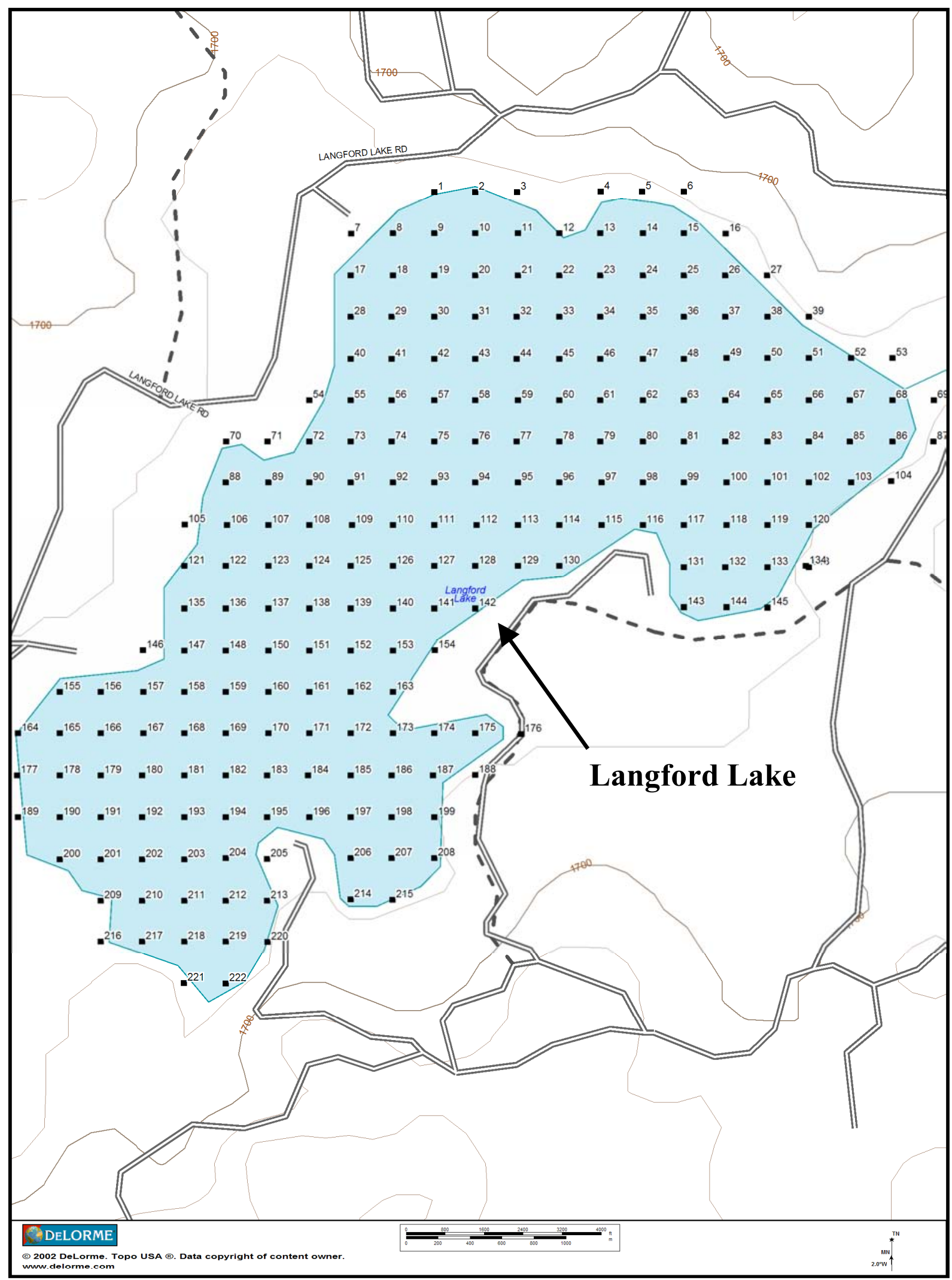

Figure 13. Langford Lake, Gogebic County, MI, aquatic plant survey locations - 2002. Squares on lake map indicate discrete GPS sampling points 


\begin{tabular}{|c|c|c|}
\hline \multicolumn{3}{|c|}{$\begin{array}{l}\text { Table } 13 \\
\text { Langford Lake, Gogebic County, MI, Aquatic Plant Survey Results - } \\
2002\end{array}$} \\
\hline Species & CoC Rating & $\%$ Occurrence \\
\hline Brasenia schreberi & 6 & 8.59 \\
\hline Ceratophyllum demersum & 3 & 3.13 \\
\hline Chara spp & & 3.91 \\
\hline Eleocharis acicularis & 5 & 0.78 \\
\hline Eleocharis palustris & 6 & 1.56 \\
\hline Elodea canadensis & 6 & 13.28 \\
\hline Eriocaulon aquaticum & 9 & 0.78 \\
\hline Lemna triscula & 6 & 0.78 \\
\hline Lobelia dortmanna & 10 & 3.13 \\
\hline Megalodonta beckii & 8 & 3.13 \\
\hline Myriophyllum farwellii & 8 & 1.56 \\
\hline Myriophyllum sibiricum & 6 & 0.78 \\
\hline Myriophyllum spicatum & & 0.78 \\
\hline Myriophyllum tenellum & 10 & 0.78 \\
\hline Najas flexilis & 6 & 2.34 \\
\hline Nuphar lutea ssp variegata & 6 & 7.81 \\
\hline Nymphaea odorata & 6 & 13.28 \\
\hline Pontedaria cordata & 8 & 1.56 \\
\hline Polygonum amphibium & 5 & 2.34 \\
\hline Potamogeton amplifolius & 7 & 33.59 \\
\hline Potamogeton epihydrus & 8 & 0.78 \\
\hline Potamogeton gramineus & 7 & 20.31 \\
\hline Potamogeton richardsonii & 5 & 34.38 \\
\hline Potamogeton robbinsii & 8 & 17.19 \\
\hline Potamogeton zosteriformis & 6 & 21.09 \\
\hline Scirpus acutus & 6 & 11.72 \\
\hline Sparganium chlorocarpum & 8 & 0.78 \\
\hline Sparganium eurycarpum & 5 & 0.78 \\
\hline Utricularia intermedia & 9 & 1.56 \\
\hline Utricularia vulgaris & 7 & 2.34 \\
\hline Vallisneria americana & 6 & 4.69 \\
\hline
\end{tabular}




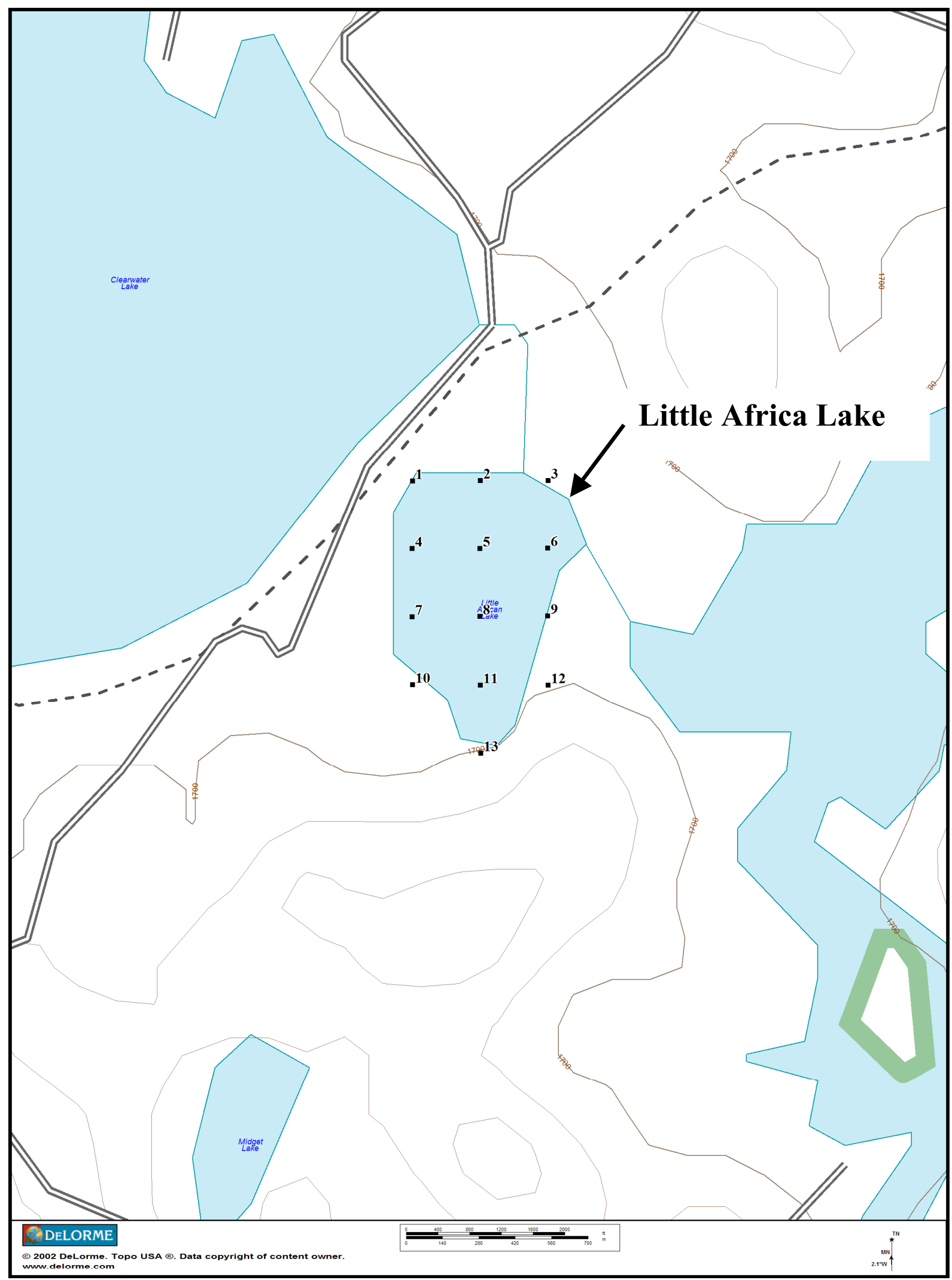

Figure 14. Little Africa Lake, Gogebic County, MI, aquatic plant survey locations - 2002. Squares on lake map indicate discrete GPS sampling points 


\begin{tabular}{|c|c|c|}
\hline \multicolumn{3}{|c|}{$\begin{array}{l}\text { Table } 14 \\
\text { Little Africa Lake, Gogebic County, MI, Aquatic Plant Survey Results } \\
-2002\end{array}$} \\
\hline Species & CoC Rating & \% Occurrence \\
\hline Brasenia schreberi & 6 & 58.33 \\
\hline Ceratophyllum demersum & 3 & 16.67 \\
\hline Isoetes lacustris & 8 & 8.33 \\
\hline Najas flexilis & 6 & 8.33 \\
\hline Nuphar lutea ssp variegata & 6 & 41.67 \\
\hline Nymphaea odorata & 6 & 33.33 \\
\hline Pontedaria cordata & 8 & 33.33 \\
\hline Potamogeton amplifolius & 7 & 16.67 \\
\hline Potamogeton epihydrus & 8 & 25.00 \\
\hline Stuckenia pectinata & 3 & 8.33 \\
\hline Potamogeton robbinsii & 8 & 8.33 \\
\hline Sparganium augustifolium & 10 & 25.00 \\
\hline Utricularia vulgaris & 7 & 58.33 \\
\hline
\end{tabular}

\section{Long Lake}

Long Lake has a surface area of 168 acres, a mean depth of $15 \mathrm{ft}$ (Table 1), and a maximum depth of about $60 \mathrm{ft}$ in the eastern end of the lake (Figure 15). A rocky reef reaches up to within a few feet of the surface directly across from the boat ramp at the same end of the lake. The lakeshore is mostly undeveloped. Most of the shoreline gradually slopes into deeper water, although a few areas have steep drop-offs. A small inlet stream comes in at the west end of the lake. The water was relatively clear with an MRD of $18 \mathrm{ft}$ (Table 1). About 50 percent of the lake has some vegetation based on survey data, and 65 percent of sample locations fell within the MRD (Table 2). Eleocharis smallii forms an emergent community sometimes mixed with Carex lasiocarpa on shallow flats, most common on the north shore of the lake, but also on the south shore at the west end of the lake. Otherwise, Long Lake was dominated by a low-growing vegetative community (Table 15) with Myriophyllum tenellum being the most common species, occurring in 50 percent of all plots (Table 3). Associated species included Eriocaulon aquaticum (18 percent), Eleocharis acicularis (16 percent), Isoetes spp (16 percent), and Isoetes lacustris (14 percent). Isoetes spp collections were often difficult to identify to species due to the fragmentary nature of many of the collections; these were likely Isoetes lacustris. Aquatic mosses also were common but not recorded. Pondweeds were not common in this lake, although Potamogeton natans was a dominant in shallow bays at the northwest end of the lake. Gratiola aurea, an STE, was quite common (23 percent). A total of 17 native plant species were found, the $I$ was 34 , and the overall $\mathrm{CoC}_{\text {avg }}$ was 7.8. Eurasian watermilfoil could become established in up to 50 percent of the lake based on the MRD. The substrate and plant species that occur in the lake indicate that Eurasian watermilfoil may not reach nuisance levels with respect to recreation and aesthetics. Localized infestations, however, could significantly displace native submersed plant populations. 


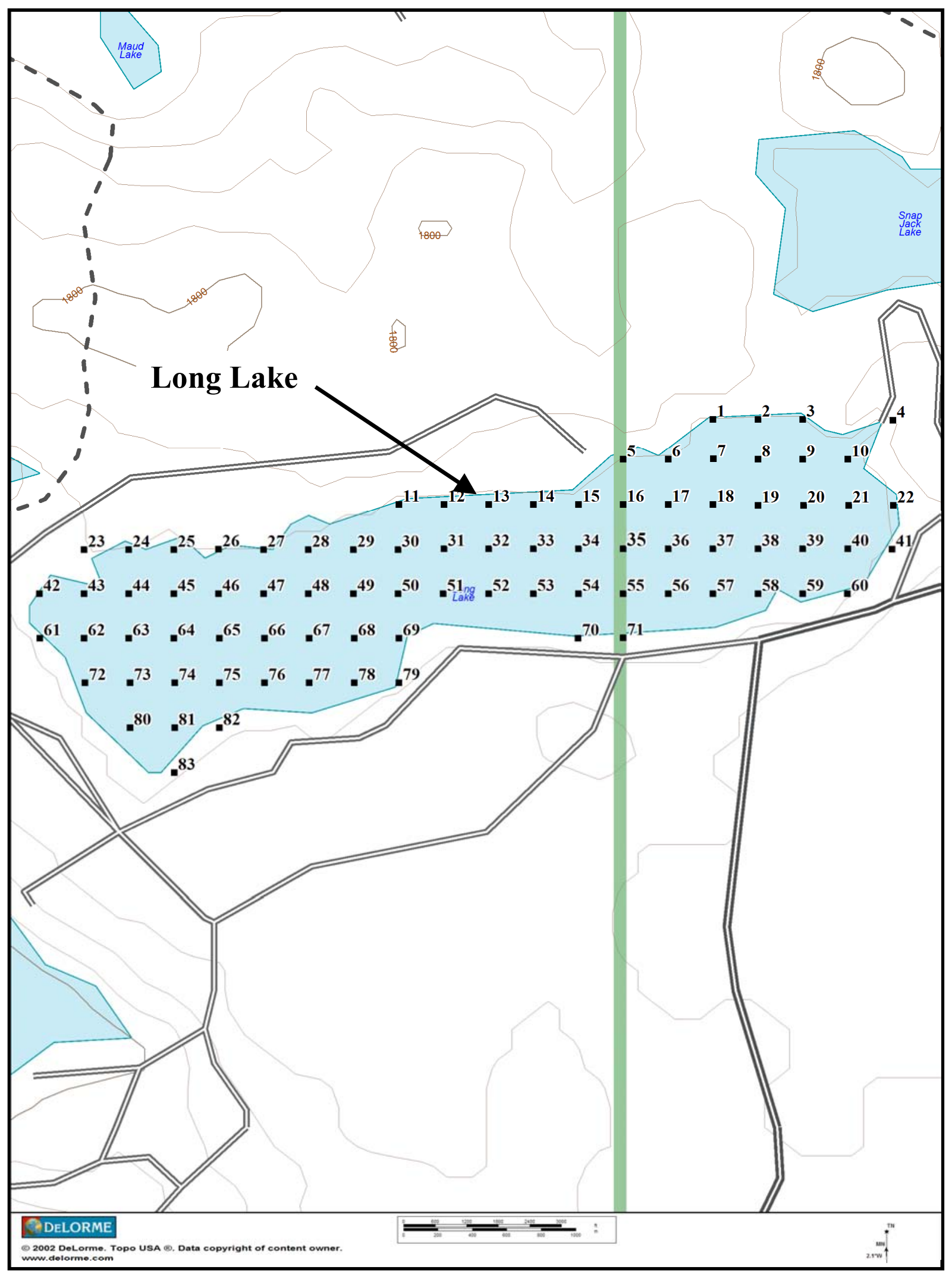

Figure 15. Long Lake, Gogebic County, MI, aquatic plant survey locations - 2002. Squares on lake map indicate discrete GPS sampling points 


\begin{tabular}{|c|c|c|}
\hline \multicolumn{3}{|c|}{$\begin{array}{l}\text { Table } 15 \\
\text { Long Lake, Gogebic County, MI, Aquatic Plant Survey Results - } \\
2002\end{array}$} \\
\hline Species & CoC Rating & $\%$ Occurrence \\
\hline Carex lasiocarpa & 9 & 2.27 \\
\hline Cladium mariscoides & 10 & 2.27 \\
\hline Dulichium arundinaceum & 9 & 2.27 \\
\hline Eleocharis acicularis & 5 & 15.91 \\
\hline Elocharis smallii & 6 & 11.36 \\
\hline Eriocaulon aquaticum & 9 & 18.18 \\
\hline Gratiola aurea & 10 & 22.73 \\
\hline Isoetes lacustris & 8 & 13.64 \\
\hline Isoetes echinospora & 8 & 2.27 \\
\hline Isoetes spp & 8 & 15.91 \\
\hline Lobelia dortmanna & 10 & 2.27 \\
\hline Lysimachia terrestris & 7 & 2.27 \\
\hline Myriophyllum tenellum & 10 & 50.00 \\
\hline Potamogeton natans & 5 & 4.55 \\
\hline Potamogeton pusillus ssp tenuissimus & 7 & 6.82 \\
\hline Sagittaria latifolia & 3 & Present \\
\hline Sparanguium fluctuans & 10 & 2.27 \\
\hline Utricularia resupinata & 9 & 2.27 \\
\hline Vallisneria americana & 6 & 2.27 \\
\hline
\end{tabular}

\section{Marion Lake}

Marion Lake has a surface area of 252 acres (Figure 16), with a mean depth of $17 \mathrm{ft}$ (Table 1). The water was relatively clear with an MRD of $17 \mathrm{ft}$ (Table 1). Only about 25 percent of the lake has some vegetation based on survey data, even though 57 percent of sample points fell within the MRD (Table 2). The substrate was mostly hard bottom consisting of rock, gravel, or sand. Aquatic vegetation was sparse and scattered. The most common species (Table 16) was the floating leaf plant, Nymphaea odorata. Submersed species occurred mostly in very shallow water, and included small plants such as Eriocaulon aquaticum, Juncus pelocarpus, Lobelia dortmanna, and Myriophyllum tenellum, which are indicative of relatively pristine systems based on their $\mathrm{COC}_{\mathrm{avg}}$ rating. One dense stand of Potamogeton amplifolius was located at the northeast end of the lake, and according to residents the stand had appeared only in the last couple of years. The total number of species was 19, the $I$ was 31.8, and the $\mathrm{CoC}_{\mathrm{avg}}$ rating was 7.3. Eurasian watermilfoil could become established in up to 57 percent of the lake based on the MRD. The substrate and plant survey data indicated that Eurasian watermilfoil may not reach widespread nuisance levels with respect to recreation and aesthetics. The existence of the dense stand of $P$. amplifolius suggested that Eurasian watermilfoil could reach nuisance levels in localized areas. Localized infestations could significantly displace native submersed plant populations. 


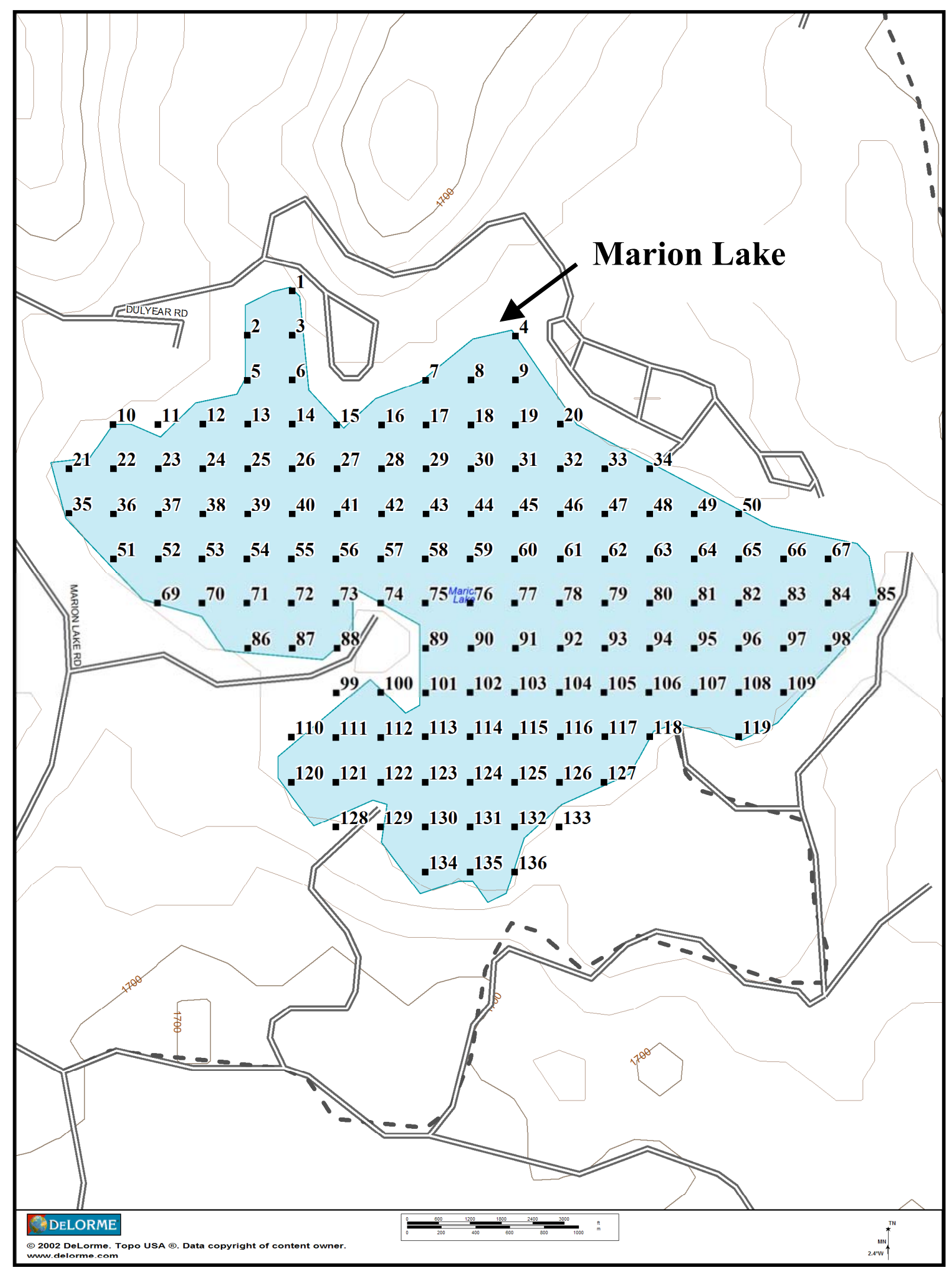

Figure 16. Marion Lake, Gogebic County, MI, aquatic plant survey locations - 2002. Squares on lake map indicate discrete GPS sampling points 


\begin{tabular}{|c|c|c|}
\hline \multicolumn{3}{|c|}{$\begin{array}{l}\text { Table } 16 \\
\text { Marion Lake, Gogebic County, MI, Aquatic Plant Survey Results - } \\
2002\end{array}$} \\
\hline Species & CoC Rating & $\%$ Occurrence \\
\hline Dulichium arundinaceum & 9 & 3.51 \\
\hline Chara spp & & 3.51 \\
\hline Elodea canadensis & 6 & 7.02 \\
\hline Equisetum fluviatile & 7 & 1.75 \\
\hline Eriocaulon aquaticum & 9 & 10.53 \\
\hline Glyceria borealis & 8 & 1.75 \\
\hline Juncus pelocarpus & 8 & 3.51 \\
\hline Lobelia dortmanna & 10 & 7.02 \\
\hline Myriophyllum tenellum & 10 & 3.51 \\
\hline Nuphar lutea ssp variegata & 6 & 5.26 \\
\hline Nymphaea odorata & 6 & 15.79 \\
\hline Potamogeton amplifolius & 7 & 3.51 \\
\hline Potamogeton epihydrus & 8 & 5.26 \\
\hline Potamogeton natans & 5 & 3.51 \\
\hline Ranunculus flammula & 9 & 5.26 \\
\hline Sagittaria latifolia & 3 & Present \\
\hline Scirpus acutus & 6 & 3.51 \\
\hline Sparganium augustifolium & 9 & 1.75 \\
\hline Sparganium eurycarpum & 5 & 5.26 \\
\hline
\end{tabular}

\section{Moon Lake}

Moon Lake had a surface area of 93 acres (Figure 17), with a mean depth of $20 \mathrm{ft}$ and a maximum depth of $40 \mathrm{ft}$. The water was very clear with an MRD of $39 \mathrm{ft}$ (Table 1). Only about 34 percent of the lake had some vegetation based on survey data, but 100 percent of sample points fell within the MRD (Table 2) because of the extremely clear water. The substrate was mostly hard bottom consisting of rock, gravel, or sand. The most common species (Table 17) were the floating leaf plants such as Brasenia schreberi, Nuphar lutea ssp variegata, and Nymphae odorata, and emergent plants including Sparganium augustifolium, Juncus effusus, and Dulichium arundinaceum. Submersed plants were rare and included Eleocharis acicularis, Eriocaulon aquaticum, Juncus pelocarpus, and Myriophyllum tenellum. The total number of species included was 12, the $I$ was 26 , and the $\mathrm{CoC}_{\text {avg }}$ rating was 7.5. Based on the MRD, Eurasian watermilfoil theoretically could colonize 100 percent of the lake. Substrate type and plant species that occur in the lake indicated that Eurasian watermilfoil populations might not reach this extreme level. Localized infestations, however, could significantly displace native submersed plant populations. 


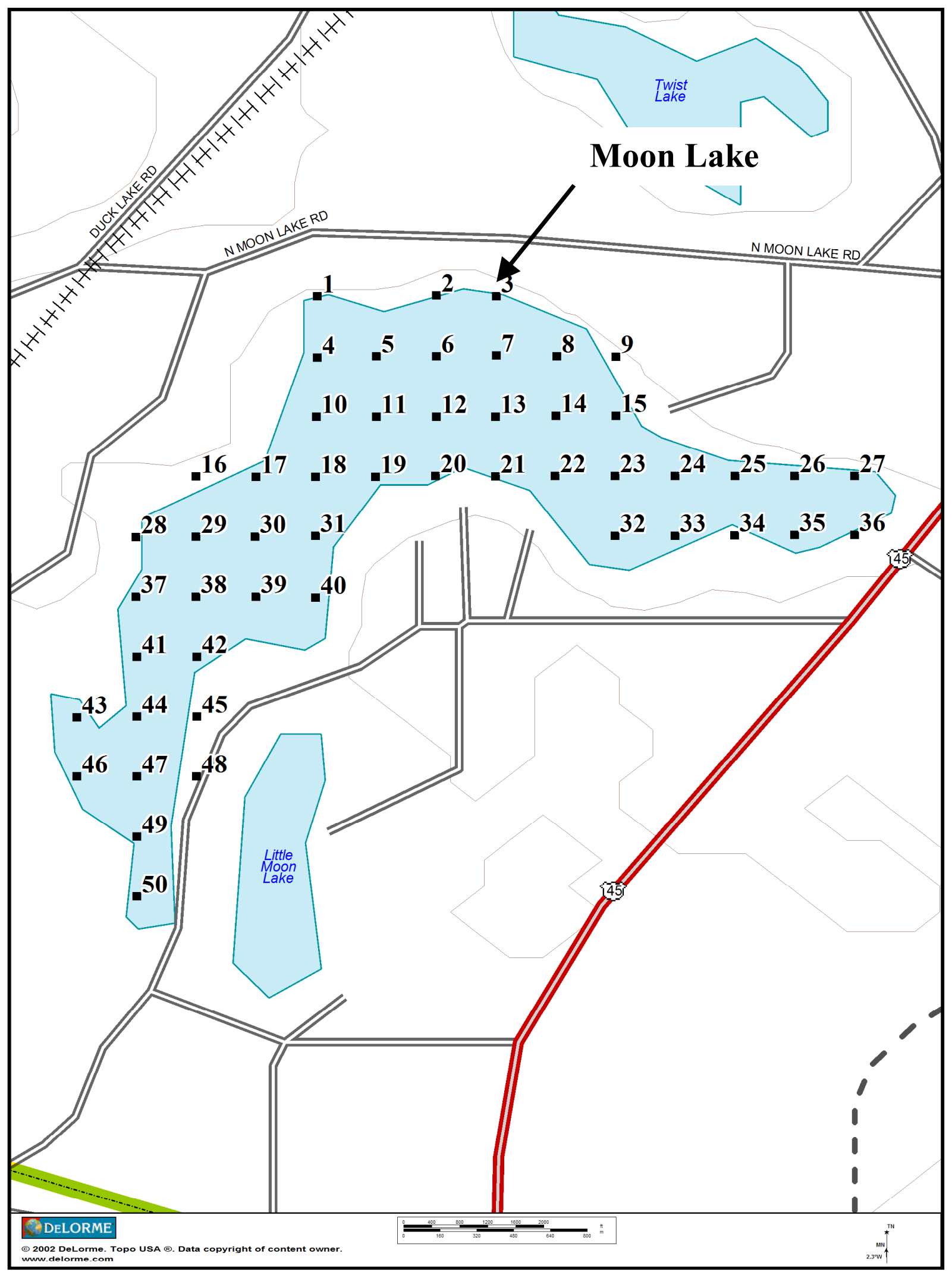

Figure 17. Moon Lake, Gogebic County, MI, aquatic plant survey locations - 2002. Squares on lake map indicate discrete GPS sampling points 


\begin{tabular}{|c|c|c|}
\hline \multicolumn{3}{|c|}{$\begin{array}{l}\text { Table } 17 \\
\text { Moon Lake, Gogebic County, MI, Aquatic Plant Survey Results - } \\
2002\end{array}$} \\
\hline Species & CoC Rating & \% Occurrence \\
\hline Brasenia schreberi & 6 & 13.33 \\
\hline Dulichium arundinaceum & 9 & 6.67 \\
\hline Eleocharis acicularis & 5 & 13.33 \\
\hline Eriocaulon aquaticum & 9 & 3.33 \\
\hline Juncus effuses & 4 & 10.00 \\
\hline Juncus pelocarpus & 8 & 6.67 \\
\hline Myriophyllum tenellum & 10 & 3.33 \\
\hline Nuphar lutea ssp variegata & 6 & 6.67 \\
\hline Nymphaea odorata & 6 & 13.33 \\
\hline Ranunculus flammula & 9 & 3.33 \\
\hline Sparganium augustifolium & 9 & 6.67 \\
\hline Utricularia resupinata & 9 & 3.33 \\
\hline
\end{tabular}

\section{Tamarack Lake}

Tamarack Lake has a surface area of 283 acres (Figure 18) with a mean depth of $11 \mathrm{ft}$ (Table 1). The water was darkly stained with humic acids and tannins; therefore, clarity was relatively poor with an MRD of only $9 \mathrm{ft}$ (Table 1). Consequently, only about 18 percent of the lake has some vegetation based on survey data, and only 33 percent of sample points fell within the MRD (Table 2). The substrate was mostly hard bottom consisting of rock, gravel, or sand, except for wetlands at the southwest end where a stream flowed into the lake. Sediment near the stream was soft and rich in organic matter. Dense plant stands including native pondweeds and milfoils were concentrated here. Stands of Vallisneria americana and the floating leaf plant Nymphaea odorata scattered in other parts of the lake (Table 18). The total number of species was 14, the $I$ was 22.4, and the $\mathrm{CoC}_{\text {avg }}$ rating was 6.0. Eurasian watermilfoil could become established in up to 33 percent of the lake based on the MRD. The substrate and plant survey data indicated that Eurasian watermilfoil may not reach widespread nuisance levels, but could reach nuisance levels in localized areas. These localized infestations could significantly displace native submersed plant populations.

\section{Taylor Lake}

Taylor Lake has a surface area of 110 acres, with a mean depth of $20 \mathrm{ft}$ (Table 1). Although relatively undeveloped, a small USFS campground is located at the side of the lake (Figure 19). The surrounding shore is generally steep with a drop-off. The 40-ft maximum depth is reached near the center of the lake. Shallower flats near the lake inlet at the north end and outlet at the south end have soft silty organic sediments. The lake had an MRD of $9.8 \mathrm{ft}$ (Table 1). 


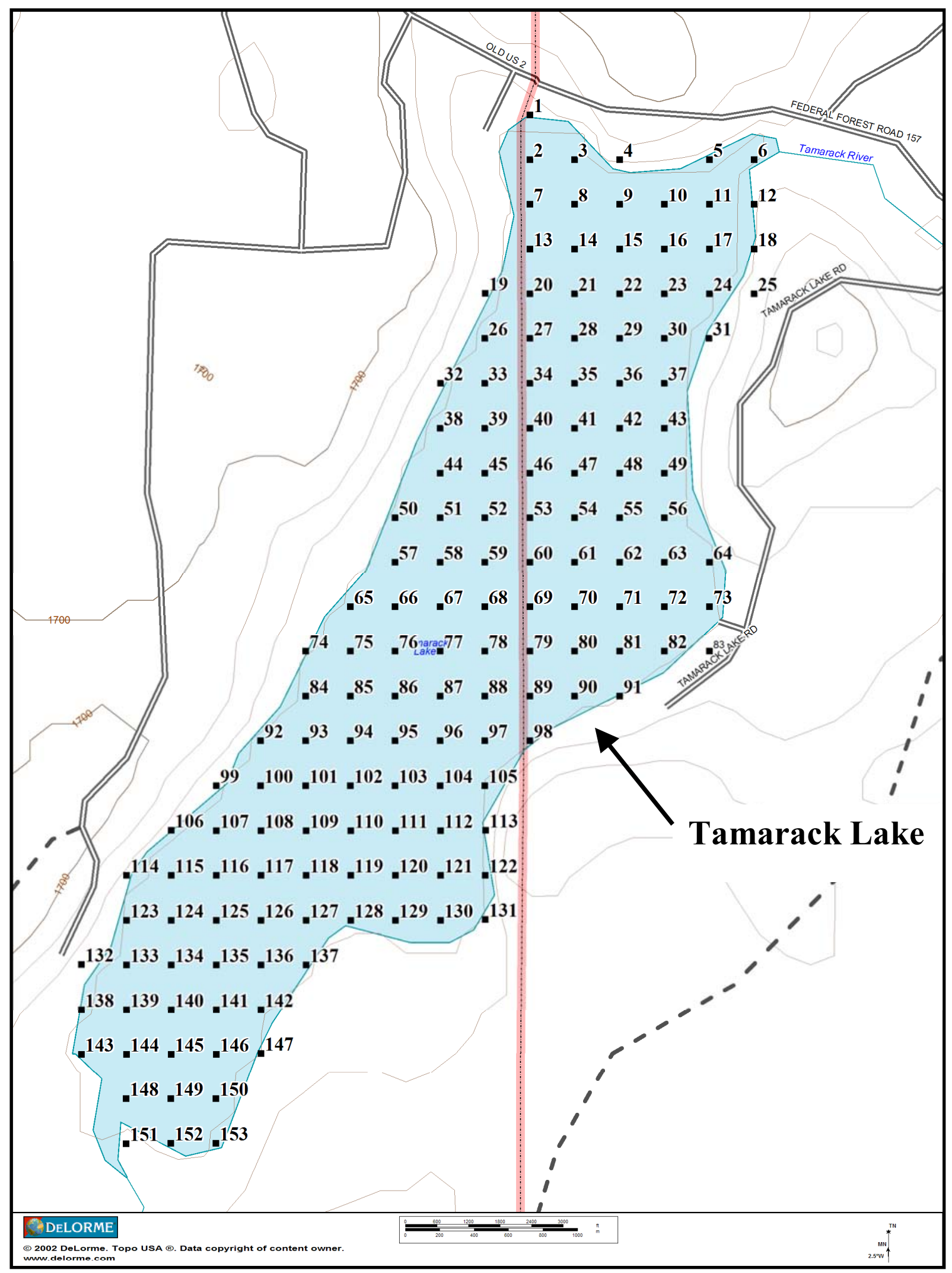

Figure 18. Tamarack Lake, Gogebic County, MI, aquatic plant survey locations - 2002. Squares on lake map indicate discrete GPS sampling points 


\begin{tabular}{|c|c|c|}
\hline \multicolumn{3}{|c|}{$\begin{array}{l}\text { Table } 18 \\
\text { Tamarack Lake, Gogebic County, MI, Aquatic Plant Survey Results - } \\
2002\end{array}$} \\
\hline Species & CoC Rating & $\%$ Occurrence \\
\hline Ceratophyllum demersum & 3 & 4.65 \\
\hline Elodea canadensis & 6 & 4.65 \\
\hline Myriophyllum alterniflorum & 10 & 2.33 \\
\hline Myriophyllum heterophyllum & 7 & 2.33 \\
\hline Najas flexilis & 6 & 2.33 \\
\hline Nuphar lutea ssp variegata & 6 & 4.65 \\
\hline Nymphaea odorata & 6 & 18.60 \\
\hline Potamogeton pusillus & 7 & 2.33 \\
\hline Potamogeton richardsonii & 5 & 18.60 \\
\hline Potamogeton robbinsii & 8 & 13.95 \\
\hline Potamogeton zosteriformis & 6 & 2.33 \\
\hline Typha latifolia & 1 & 2.33 \\
\hline Utricularia vulgaris & 7 & 2.33 \\
\hline Vallisneria americana & 6 & 27.91 \\
\hline
\end{tabular}

About 23 percent of the lake has some vegetation based on survey data, and 31 percent of sample points fell within the MRD (Table 2). The broad inlet flowing through a peatland area had the most diverse vegetation in Taylor Lake with a mix of many floating, emergent, and submerged species (Table 19) such as Brasenia schreberi, Potamogeton natans, Nuphar lutea ssp variegata, Najas flexilis, Utricularia vulgaris, and other species. The outlet, Taylor Creek, is in a broad bay with floating vegetation of Brasenia schreberi and water lilies with pondweeds beneath. Otherwise vegetation is fairly sparse and confined to a narrow belt along the shoreline. Brasenia schreberi is the most common plant in the lake, occurring on half of all plots (Table 4), at both inlet and outlet areas and in shallow locations along much of the shore. Utricularia vulgaris is also widespread (31 percent of all plots). There were 22 species found in Taylor Lake with a $\mathrm{CoC}_{\text {avg }}$ rating of 6.4 and an $I$ of 30 . Eurasian watermilfoil could become established in up to 31 percent of the lake based on the MRD. The substrate and plant species that occurred in the lake indicated that Eurasian watermilfoil could reach nuisance levels with respect to recreation and aesthetics. Infestations could also have significant adverse impacts on the submersed plant populations. Once established in Taylor Lake, Eurasian watermilfoil could quickly spread to other lakes in the area via boat traffic, water currents, and animals. 


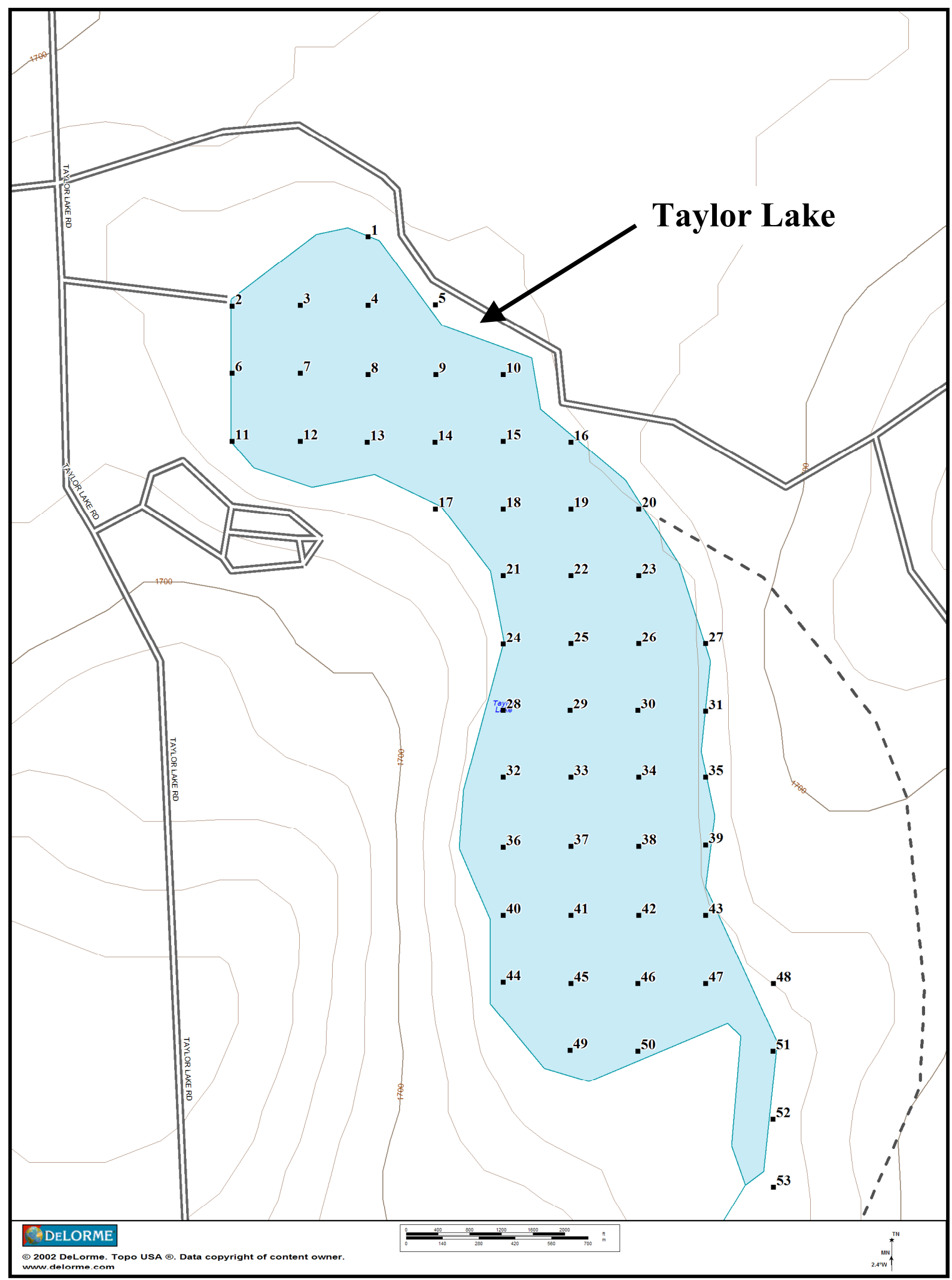

Figure 19. Taylor Lake, Gogebic County, MI, aquatic plant survey locations - 2002. Squares on lake map indicate discrete GPS sampling points 


\begin{tabular}{|c|c|c|}
\hline \multicolumn{3}{|c|}{$\begin{array}{l}\text { Table } 19 \\
\text { Taylor Lake, Gogebic County, MI, Aquatic Plant Survey Results - } \\
2002\end{array}$} \\
\hline Species & CoC Rating & $\%$ Occurrence \\
\hline Brasenia schreberi & 6 & 50.00 \\
\hline Dulichium arundinaceum & 9 & Present \\
\hline Elodea canadensis & 6 & 12.50 \\
\hline Equisetum fluviatile & 7 & Present \\
\hline Isoetes lacustris & 8 & 12.50 \\
\hline Juncus brevicaudatus & 6 & Present \\
\hline Juncus pelocarpus & 8 & Present \\
\hline Myriophyllum sibiricum & 6 & 12.50 \\
\hline Najas flexilis & 6 & 18.75 \\
\hline Nuphar lutea ssp variegata & 6 & 18.75 \\
\hline Nymphaea odorata & 6 & 6.25 \\
\hline Potamogeton amplifolius & 7 & 12.50 \\
\hline Potamogeton epihydrus & 8 & 6.25 \\
\hline Potamogeton gramineus & 7 & 6.25 \\
\hline Potamogeton natans & 5 & 12.50 \\
\hline Potamogeton pusillus ssp tenuissimus & 7 & 12.50 \\
\hline Sagittaria latifolia & 3 & Present \\
\hline Scirpus tabernaemontani & 4 & Present \\
\hline Sparganium fluctuans & 10 & 12.50 \\
\hline Stuckenia pectinata & 3 & 6.25 \\
\hline Utricularia vulgaris & 7 & 31.25 \\
\hline Vallisneria americana & 6 & 6.25 \\
\hline
\end{tabular}

\section{Thousand Island Lake}

Thousand Island Lake is the largest lake in the Cisco Chain of Lakes. It has a surface area of 1,000 acres (Figure 20) and a mean depth of $27 \mathrm{ft}$ (Table 1) with a maximum depth of $95 \mathrm{ft}$. Numerous homes and resorts line the lakeshore. The water was relatively clear with an MRD of $18 \mathrm{ft}$ (Table 1). Thousand Island Lake is connected to Big Africa Lake, which can be reached by boat though a stream that feeds into the lake's northernmost bay. Cisco Lake is connected to Thousand Island Lake by a channel at the southwest end of the lake. About 34 percent of the lake has some vegetation based on survey data, and 42 percent of sample locations fell within the MRD (Table 2). The northern and western bays were relatively shallow $(<\mathrm{MRD})$ with mostly soft organic sediments that supported large stands of pondweeds (Table 20), including Potamogeton zosteriformis, P. robbinsii, P. richardsonii, and P. epihydrus. Elodea canadensis and Myriophyllum sibiricum were also common in these areas. The southeast and east sections of lakes were much deeper ( $>90 \mathrm{ft}$ in some areas), and the substrate tended to be gravel or sand. Many plants were common in the shallow areas, but this area was too deep ( $>$ MRD) to support aquatic plants. The number of species found was 31, the greatest of any lake surveyed. The $\mathrm{CoC}_{\mathrm{avg}}$ rating was 6.5 , and the $I$ was 36.0. Eurasian watermilfoil could become established in up to 


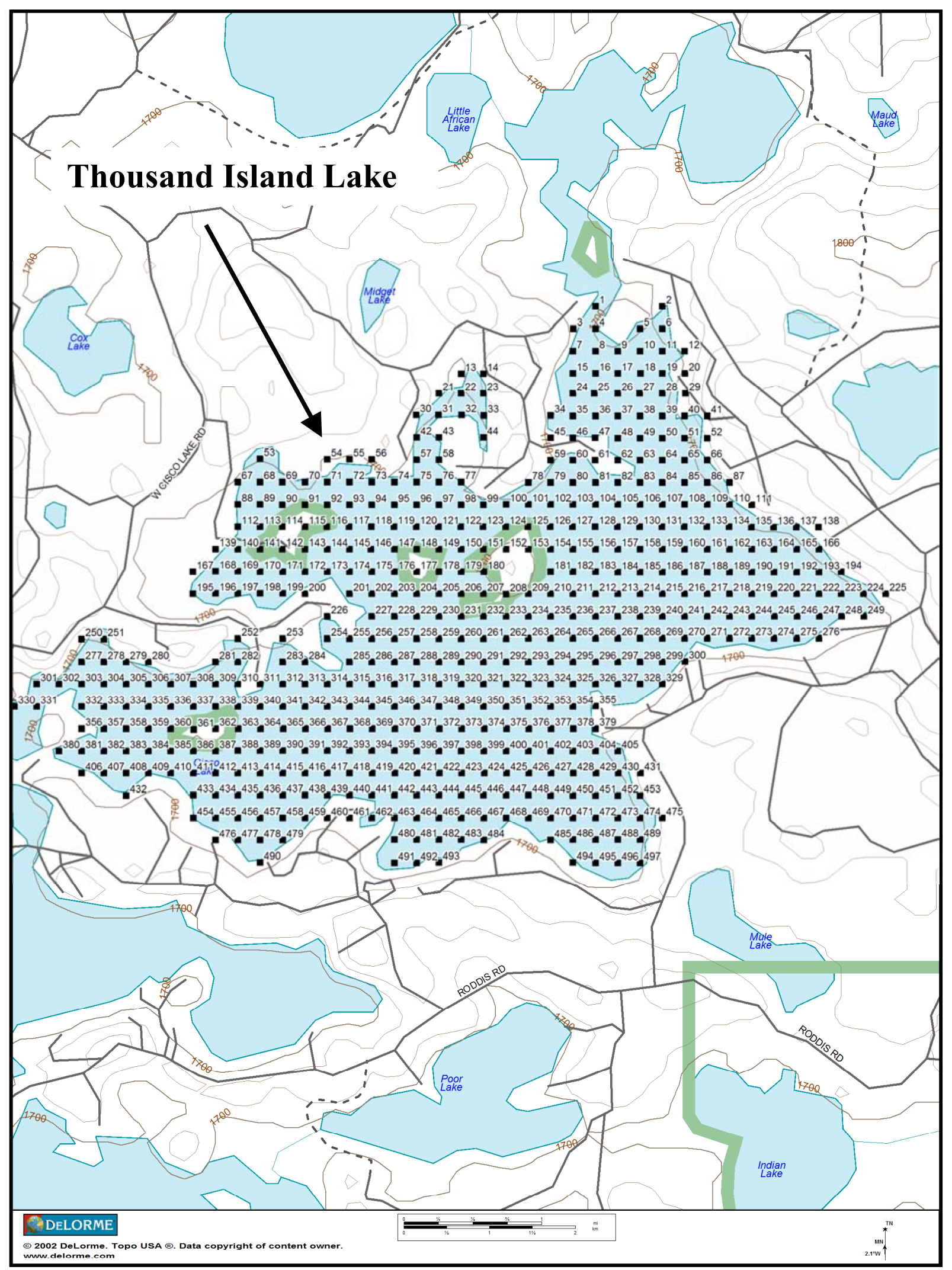

Figure 20. Thousand Island Lake, Gogebic County, MI, aquatic plant survey locations -2002. Squares on lake map indicate discrete GPS sampling points 


\begin{tabular}{|c|c|c|}
\hline \multicolumn{3}{|c|}{$\begin{array}{l}\text { Table } 20 \\
\text { Thousand Island Lake, Gogebic County, MI, Aquatic Plant Survey } \\
\text { Results - } 2002\end{array}$} \\
\hline Species & CoC Rating & $\%$ Occurrence \\
\hline Brasenia schreberi & 6 & 4.67 \\
\hline Ceratophyllum demersum & 3 & 6.67 \\
\hline Chara spp & & 10 \\
\hline Elocharis acicularis & 5 & 0.67 \\
\hline Elodea canadensis & 6 & 34.67 \\
\hline Zosterella dubia & 6 & 0.67 \\
\hline Iris versicolor & 5 & 1.33 \\
\hline Megalodonta beckii & 8 & 0.67 \\
\hline Myriophyllum sibiricum & 6 & 24.67 \\
\hline Myriophyllum farwellii & 8 & 1.33 \\
\hline Najas flexilis & 6 & 6.00 \\
\hline Nuphar lutea ssp variegata & 8 & 12.00 \\
\hline Nymphaea odorata & 6 & 17.33 \\
\hline Pontedaria cordata & 8 & 8.00 \\
\hline Potamogeton amplifolius & 7 & 20.67 \\
\hline Potamogeton epihydrus & 8 & 10.00 \\
\hline Potamogeton friesii & 8 & 4.00 \\
\hline Potamogeton gramineus & 7 & 0.67 \\
\hline Potamogeton natans & 5 & 7.33 \\
\hline Potamogeton pusillus & 7 & 7.33 \\
\hline Potamogeton richardsonii & 5 & 32.67 \\
\hline Potamogeton robbinsii & 8 & 26.00 \\
\hline Potamogeton zosteriformis & 6 & 14.00 \\
\hline Ranunculus longirostris (aquaticus) & 8 & 2.00 \\
\hline Riccia fluitans & 7 & 0.67 \\
\hline Scirpus subterminalis & 9 & 0.67 \\
\hline Sparganium augustifolium & 9 & 2.00 \\
\hline Sparganium eurycarpum & 5 & 2.00 \\
\hline Typha latifolia & 1 & 2.00 \\
\hline Utricularia vulgaris & 7 & 4.00 \\
\hline Vallisneria americana & 6 & 8.00 \\
\hline
\end{tabular}

42 percent of the lake based on the MRD. The substrate and plant species that occur in the lake indicate that Eurasian watermilfoil could impact recreation and aesthetics, particularly in the northern and western portions of the lakes. Infestations could also have significant adverse impacts on the submersed plant populations. Once established in Thousand Island Lake, Eurasian watermilfoil could quickly spread to other lakes in the Cisco Chain of Lakes via boat traffic, water currents, and animals. 


\section{Conclusion and Recommendations}

\section{Conclusion}

Lakes of the Michigan western Upper Peninsula are valuable natural resources, supporting healthy and diverse native aquatic plant populations, including sensitive and rare species of the 16 lakes surveyed, only 2 (Crooked Lake and Langford Lake) had small infestations of Eurasian watermilfoil. While this invasive plant is not currently widespread, if left unchecked it has the potential to cause major adverse environmental, recreational, economic, and aesthetic impacts to the area.

\section{Recommendations}

a. Annual vegetation surveys should be conducted during the growing season on lakes in the Cisco Chain and the surrounding region to identify the presence of Eurasian watermilfoil. A high priority for the vegetation survey should be lakes with public access points, such as boat ramps and campgrounds.

$b$. If Eurasian watermilfoil is found, a rapid response is required to control or eradicate the infestation through hand pulling or diver dredging in small areas, spot treatments of aquatic herbicides in larger areas, or an integration of both physical and chemical methods.

c. Lake communities should coordinate with local government entities, state agencies (e.g., MI-DNR, MI-DEQ, and WI-DNR), and Federal agencies such as USACE Detroit District and the USFS, to identify, prevent, and control Eurasian watermilfoil in the western Upper Peninsula of Michigan. 


\section{References}

Barko, J. W., Adams, M. S., and Clesceri, N. L. (1986). "Environmental factors and their consideration in the management of submersed aquatic vegetation: A review." J. Aquat. Plant Manage. 24: 1-10.

Borman, S., Korth, R., and Temte, J. (1997). Through the Looking Glass. Reindl Printing, Inc., Merrill, WI.

Boylen, C. W., Eichler, L. W., and Madsen, J. D. (1999). "Loss of native aquatic plant species in a community dominated by Eurasian watermilfoil." Hydrobiologia 415:207-211.

Colle, D. E., and Shireman, J. W. (1980). Coefficients of condition for largemouth bass, bluegill, and radar sunfish in hydrilla-infested lakes. Trans. Amer. Fish. Soc. 109:521-531.

Crow, G. E., and Hellquist, C. B. (2000a). Aquatic and Wetland Plants of Northeastern North America, Volume one Pteridophytes, Gymnosperms and Angiosperms: Dicotyledons. The University of Wisconsin Press, Madison, WI.

(2000b). Aquatic and Wetland Plants of Northeastern North America, Volume two, Angiosperms: Monocotyledons. The University of Wisconsin Press, Madison, WI.

Eichler, L. W., Bombard, R. T., Sutherland, J. W., and Boylen, C. W. (1993). "Suction harvesting of Eurasian watermilfoil and its effect on native plant communities." J. Aquat. Plant Manage. 31: 144-148.

. (1995). "Recolonization of the littoral zone by macrophytes following the removal of benthic barrier material." J. Aquat. Plant Manage. 33: $51-54$

Engel, S. (1984). "Evaluating stationary blankets and removable screens for macrophyte control in lakes." J. Aquat. Plant Manage. 22: 43-48.

. (1995). "Eurasian watermilfoil as a fishery management tool."

Fisheries 20:20-27. 
Getsinger, K. D., Davis, G. J., and Brinson, M. M. (1982). "Changes in a Myriophyllum spicatum L. community following a 2,4-D treatment." $J$. Aquat. Plant Manage. 20: 4-8.

Getsinger, K. D., and Netherland, M. D. (1997). "Herbicide concentration/ exposure time requirements for controlling submersed aquatic plants: Summary of research accomplishments," Miscellaneous Report A-97-2. U.S. Army Engineer Waterways Experiment Station, Vicksburg, MS.

Getsinger, K. D., Poovey, A. G., James, W. F., Stewart, R. M., Grodowitz, M. J., Maceina, M. J., and Newman, R. M. (2002). "Management of Eurasian watermilfoil in Houghton Lake, Michigan: Workshop Summary," Technical Report ERDC/EL TR-02-24. U.S. Army Engineer Research and Development Center, Vicksburg, MS.

Getsinger, K. D., Turner, E. G., Madsen, J. D., and Netherland, M. D. (1997). "Restoring native vegetation in a Eurasian watermilfoil-dominated plant community using the herbicide triclopyr." Regul. Rivers: Res. Mgmt. 13:357375 .

Green, W. R., and Westerdahl, H. E. (1990). "Response of Eurasian watermilfoil to 2,4-D concentrations and exposure times." J. Aquat. Plant Manage. 28: 27-32.

Griffin, M. A., and Bernthal, T. W. (2003). "Development of a Floristic Quality Assessment Methodology For Wisconsin." Final Report to USEPA Region V, Wetland Grant \#CD975115-01-0, Madison, WI.

Gunnison, G., and Barko, J. W. (1992). Factors influencing gas evolution beneath a benthic barrier. J. Aquat. Plant Manage. 30: 23-28.

Keast, A. (1984). "The introduced macrophyte, Myriophyllum spicatum, as a habitat for fish and their invertebrate prey." Can. J. Zool. 62:1289-1303.

Madsen, J. D. (1999). "Point intercept and line intercept methods for aquatic plant management." Technical Note (TN) APCRP-MI-02. U.S. Army Engineer Research and Development Center, Vicksburg, MS.

. (2000). "Advantages and disadvantages of aquatic plant management techniques.” ERDC/EL MP-00-1. U.S. Army Engineer Research and Development Center, Vicksburg, MS.

Madsen, J. D., Sutherland, J. W., Bloomfield, J. A., Eichler, L. W., and Boylen, C. W. (1991). "The decline of native vegetation under dense Eurasian watermilfoil canopies.” J. Aquat. Plant Manage. 29: 94-99.

Netherland, M. D., Green, W. R., and Getsinger, K. D. (1991). "Endothall concentration and exposure time relationships for the control of Eurasian watermilfoil and hydrilla.” J. Aquat. Plant Manage. 29: 61-67. 
Netherland, M. D., Getsinger, K. D., and Turner, E. G. (1993). "Fluridone concentration and exposure time requirements for control of hydrilla and Eurasian watermilfoil.” J. Aquat. Plant Manage. 32: 189-194.

Netherland, M. D., and Getsinger, K. D. (1992). "Efficacy of triclopyr on Eurasian watermilfoil: Concentration and exposure time effects." J. Aquat. Plant Manage. 30: 1-5.

. (1995a). "Laboratory evaluation of threshold fluridone concentrations under static conditions for controlling hydrilla and Eurasian watermilfoil.” J. Aquat. Plant Manage. 33: 33-36.

. (1995b). "Potential control of hydrilla and Eurasian watermilfoil under various half-life scenarios.” J. Aquat. Plant Manage. 33: 36-42.

Netherland, M. D., Getsinger, K. D., and Skogerboe, J. G. (1997). "Mesocosm evaluation of the species-selective potential of fluridone." J. Aquat. Plant Manage. 35: 41-50.

Nichols, S. A. (1994). "Evaluation of invasions and declines of submersed macrophytes for the Upper Great Lakes Region." Lake and Reserv. Manage. 10: 29-33.

. (1999). "Floristic quality assessment of Wisconsin lake plant communities with example applications." Lake and Reserv. Manage. 15: $133-141$

Nichols, S. A., and Buchan, L. A. J. (1997). "Use of native macrophytes as indicators of suitable Eurasian watermilfoil habitat in Wisconsin lakes." $J$. Aquat. Plant Manage. 35: 21-24.

Nichols, S. A., and Shaw, B. H. (1986). "Ecological life histories of the three aquatic nuisance plants, Myriophyllum spicatum, Potamogeton crispus, and Elodea canadensis." Hydrobiologia: 131: 3-21.

Parsons, J. K., Hamel, K. S., Madsen, J. D., and Getsinger, K. D. (2001). “The use of 2,4-D to selectively control an early infestation of Eurasian watermilfoil in Loon Lake, Washington," J. Aquat. Plant Manage. 39: 117-125.

Peacock, B. (1986). Sylvania. Park Press, Inc., Waite Park, MN.

Perkins, M. A., Boston, H. L., and Curren, E. F. (1980). "The use of fiberglass screens for control of Eurasian watermilfoil." J. Aquat. Plant Manage. 18: 13-19.

Pullman, G. D. (1992). "The management of Eurasian watermilfoil in Michigan." Issues in Aquatic Vegetation Management Series, Vol. 1. Midwest Aquatic Plant Management Society, Seymour, IN, 8. 
Skogerboe, J. G., and Getsinger, K. D. (2001). "Endothall species selectivity evaluation: southern latitude aquatic plant community." J. Aquat. Plant Manage. 39: 129-135.

. (2002). "Endothall species selectivity evaluation: northern latitude aquatic plant community." J. Aquat Plant Manage. 40: 1-5.

Smith, C. S., and Barko, J. W. (1990). "Ecology of Eurasian watermilfoil." J. Aquat. Plant Manage. 28: 55-64.

Valley, R. D., and Bremingan, M. T. (2002). "Effects of macrophyte bed architecture on largemouth bass foraging: Implications of exotic macrophyte invasions." Trans. Amer. Fish. Soc. 131: 234-244.

Wiley, M. J., Gordon, R. W., Waite, S. W., and Powless, T. (1984). “The relationship between aquatic macrophytes and sport fish production in Illinois ponds; a simple model." North Am. J. Fish Manage. 4:111-119. 


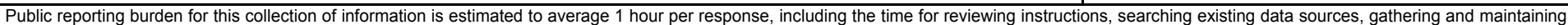

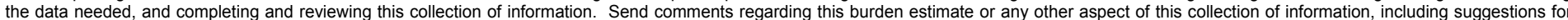

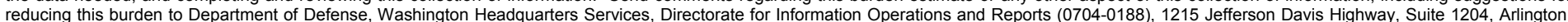

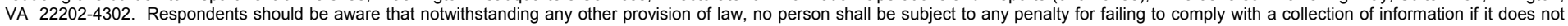
display a currently valid OMB control number. PLEASE DO NOT RETURN YOUR FORM TO THE ABOVE ADDRESS.

\begin{tabular}{l|c}
$\begin{array}{l}\text { 1. REPORT DATE (DD-MM-YYYY) } \\
\text { August } 2003\end{array}$ & $\begin{array}{c}\text { 2. REPORT TYPE } \\
\text { Final report }\end{array}$ \\
\hline
\end{tabular}

\section{TITLE AND SUBTITLE}

Invasion of Eurasian Watermilfoil in Lakes of the Western Upper Peninsula, Michigan

\section{AUTHOR(S)}

John G. Skogerboe, Angela G. Poovey, Kurt D. Getsinger, and Greg Kudray

\section{DATES COVERED (From - To)}

5a. CONTRACT NUMBER

5b. GRANT NUMBER

5c. PROGRAM ELEMENT NUMBER

5d. PROJECT NUMBER

$96 \times 3122$

5e. TASK NUMBER

\section{5f. WORK UNIT NUMBER}

8. PERFORMING ORGANIZATION REPORT NUMBER

ERDC/EL TR-03-
U.S. Army Engineer Research and Development Center

Environmental Laboratory

3909 Halls Ferry Road

Vicksburg, MS 39180-6199

\section{SPONSORING / MONITORING AGENCY NAME(S) AND ADDRESS(ES)}

U.S. Army Corps of Engineers

Washington, DC 20314-1000;

U.S. Army Engineer District, Detroit

477 Michigan Avenue

Detroit, MI 48226

\section{DISTRIBUTION / AVAILABILITY STATEMENT}

Approved for public release; distribution is unlimited.

\section{SUPPLEMENTARY NOTES}

\section{ABSTRACT}

Eurasian watermilfoil (Myriophyllum spicatum L.) has the potential to cause major long-term adverse environmental, recreational, and aesthetic impacts to the pristine lakes in the western Upper Peninsula of Michigan. At the request of the U.S. Army Engineer District, Detroit, the U.S. Army Engineer Research and Development Center evaluated 16 lakes in Gogebic County, first to verify if Eurasian watermilfoil was present in the lakes, and then to recommend spot-treatment control options for pioneer infestation of the exotic species. Surveys were conducted using a sampling grid and global positioning system method. Of the lakes surveyed, only two contained small infestations of Eurasian watermilfoil. Occurrences of rare, threatened, or endangered aquatic plants were documented during the lake evaluations.

\section{SUBJECT TERMS}

Aquatic plant control Exotic species

\section{SECURITY CLASSIFICATION OF:}

\section{a. REPORT}

UNCLASSIFIED

b. ABSTRACT
UNCLASSIFIED

Invasive species

Myriophyllum spicatum

\begin{tabular}{l|c}
$\begin{array}{l}\text { 17. LIMITATION } \\
\text { OF ABSTRACT }\end{array}$ & $\begin{array}{c}\text { 18. NUMBER } \\
\text { OF PAGES }\end{array}$ \\
& 64 \\
\hline
\end{tabular}

19a. NAME OF RESPONSIBLE PERSON

c. THIS PAGE

UNCLASSIFIED 19b. TELEPHONE NUMBER (include area code) 